Article

\title{
Deity and Display: Meanings, Transformations, and Exhibitions of Tibetan Buddhist Objects
}

\author{
Louise Tythacott ${ }^{1, *}$ and Chiara Bellini ${ }^{2}$ \\ 1 Arts Department, Northumbria University, Newcastle upon Tyne NE1 8ST, UK \\ 2 Department of History of Art and Archaeology, SOAS University of London, Thornhaugh Street, Russell \\ Square, London WC1H 0XG, UK; bellinichiara@hotmail.com \\ * Correspondence: Louise.tythacott@northumbria.ac.uk
}

Received: 2 February 2020; Accepted: 13 February 2020; Published: 27 February 2020

check for updates

\begin{abstract}
This paper analyses the values and uses of Tibetan sacred artefacts in their original contexts as well as the transformation of meanings once placed in museums. It discusses the perception of statues, paintings, ritual instruments and books from a Tibetan Buddhist perspective, examining the iconographic and iconometric functions of the images, and asserting that a primary purpose is as a 'support for practice' (tib. sku rten, 'body-support'). Sacred images represent the embodiment of the Buddhas, deities and masters and, once consecrated by lamas, are considered to have the power to confer blessings. Despite the instrumental function of such artefacts, however, it is also possible to identify and delineate a complex Himalayan concept of aesthetics. The text moves on to analyse the effects of the transition of Tibetan Buddhist images into different museological contexts, comparing the display of Tibetan material in the consecrated spaces of Himalayan monastery museums with their exhibition in secular museological sites in the West.
\end{abstract}

Keywords: Tibetan Buddhism; Buddhist art; religious images; museum; display

\section{Introduction}

Over the past decades, much has been written about the meanings attributed to religious objects displaced from their original environments and relocated to museums and exhibitions, especially in the West. ${ }^{1}$ However, the impact of the movement of Tibetan Buddhist objects into displays-both in the Himalayas and in the West-has not been analysed in such depth. ${ }^{2}$ This paper focuses on the particularities of Tibetan sacred Buddhist artefacts and the consequences of their transfer to exhibitionary sites. It is based to a large extent on research undertaken by the authors in Tibetan Buddhist monasteries in Ladakh and Nepal. ${ }^{3}$

The paper examines, first of all, the values and uses of Tibetan religious objects in their original contexts, discussing the perception of statues, paintings, ritual instruments and books from a Tibetan Buddhist perspective. It also addresses the iconographic and iconometric functions of images, asserting that a primary purpose is as a 'support for practice' (tib. sku rten, 'body-support'). Sacred images represent the embodiment of the Buddhas, deities and masters and, once consecrated

1 See for example, Clarke (2009, 2015); Marshall (2015); Mathur and Singh (2015); Paine (2000, 2013); Sullivan (2015); Suzuki (2007); Wingfield (2010).

2 Apart from the work of Clark (2016); Harris (2012); Tythacott (2017).

3 The research was made possible by an AHRC grant on 'Tibetan Buddhist Monastery Collections Today' (2016-19), which focused on the documentation of collections and development of museum displays in monasteries in Ladakh and Nepal. Christian Luczanits was the Primary Investigator (PI), Louise Tythacott the Co-Investigator (CI) and Chiara Bellini the Post-Doctoral Researcher. Chiara Bellini has also undertaken research in Ladakh, Mustang and other Himalayan regions since 2002. 
by lamas, have the power to confer blessings. Despite the instrumental function of such artefacts, however, it is possible to identify and delineate a complex Himalayan concept of aesthetics. The paper moves on to discuss the effects of the transition of such images into different contexts, comparing displays of material in the consecrated spaces of Himalayan monastery museums with exhibitions in museological sites in the West.

\section{On the Meanings and Interpretations of Tibetan and Himalayan Buddhist Art}

An evaluation of Tibetan and Himalayan Buddhist art ${ }^{4}$ demands consideration of Buddhist images and objects from the Tibetan, and more general Himalayan, point of view. ${ }^{5}$ Western anthropological and art historical approaches are not always fully appropriate when referring to Tibetan art (see Harris 2012). Western art historical perceptions tend to focus on aesthetics, and are primarily concerned with dating and iconographic identification, rather than the rationale and purpose for creating artworks or the specific cultural settings in which objects originate. ${ }^{6}$

By contrast, Tibetan Buddhists consider sacred images primarily as 'supports' or 'receptacles' (tib. rten) of the deities, and for this reason are 'the most revered Buddhist objects of devotion' (Bentor 1996, p. xx), meditation and expressions of faith, and only secondarily as aesthetically significant. A sacred receptacle such a statue or painting (tib. sku rten, 'body-supports'), 'would create faith and devotion in those who see it and induce them to generate the mind of enlightenment' (Bentor 1996, pp. 201-21) (Figure 1). As clearly expressed by Tucci, 'every mystical plane has its symbolic projection, expressed, as in a mysterious writing, by the figures of the gods; the initiate reads into them the secret instructions which will produce his palingenesis' (Tucci 1999, vol. 1, p. 287). ${ }^{7}$ In this sense, 'antiquity' and 'originality' only have a relative significance for Tibetan Buddhist practitioners: an ancient painting, for example, is valued for its apotropaic or symbolic qualities or its particular history, rather than for its rarity or aesthetic value. The aesthetic qualities are secondary to the function of the object, but this does not mean that they are irrelevant to Tibetans, as demonstrated by the extreme refinement of many sacred Buddhist works of art. From a religious point of view-and this paper deals with religion in relation to museums and not to aesthetics-only iconographic accuracy determines the authenticity and liturgical functionality of an object. It is evident, with the production and commissioning of works of art in Tibet and the Himalayan regions, that in everyday life and in practice, images are clearly appreciated and evaluated from an aesthetic point of view, as elsewhere around the world. In the same way, the concept of antiquity does not add or remove value from an object, unless a religious value is also attributed to this antiquity: the ownership of an object by a renowned master, the place where the image was kept, the type of veneration. The value that Westerners attach to an ancient object is also linked to the fact that it comes from a remote past to which we can, by virtue of the object, reconnect. For a Tibetan, the value of an object's antiquity is, above all, given by the religious value that that object has had over the centuries for devotees.

4 The term 'art' in this paper will refer to statues, paintings, as well as objects, depicting Buddhist subjects or employed for Buddhist practices. Although it is possible to discuss 'Buddhist art' in relation to precious kitchenware, rugs and jewellery enriched with Buddhist symbols and motifs, this paper will refer only to sacred images or liturgical instruments.

5 Since Tibetan Buddhist art derives from Indian Buddhist art, the perceptions of Buddhist images by Tibetans are related to that of their Indian neighbours. For a deep understanding of the perception of sacred images in Buddhist India, see Kinnard (1999).

6 As Tucci pointed out in one of the first extensive treatises on Tibetan painting, 'thus we are led, if we aim at a proper understanding of the thangkas [painted scrolls], to look into the religious world which is their base and premise, without a knowledge of which, the thangkas would remain an inexplicable mystery' (Tucci 1999, vol. 1, p. 209).

7 Even if a sacred image is a blessing for everyone, by virtue of the deity within, it expresses its full purpose when the believer is aware of its symbolic meaning. A meditation ritual based on the comprehension of the image creates a 'consubstantiation' between the sacred plane the image represents and the practitioner. He or she is spiritually unified with the object of contemplation (Tucci 1999, p. 288). 


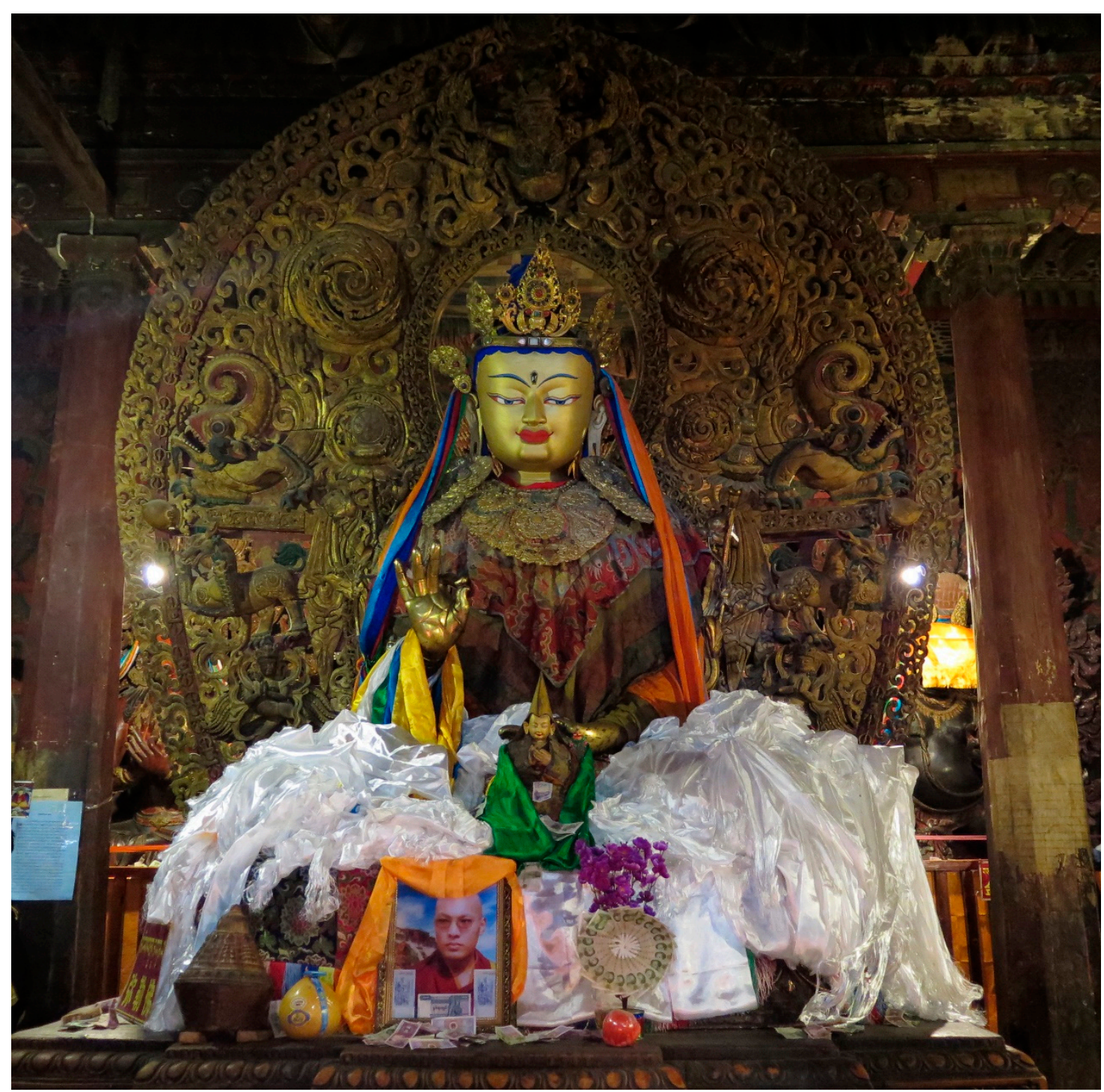

Figure 1. Silk scarfs and offerings to the statue of Maitreya, Gyantse Tsuklakhang, Tibet (photo C. Bellini 2016).

In order to fully appreciate Himalayan Buddhist art then, it is necessary to understand religious meanings and specific symbolism rather than aesthetic criteria. In addition to the spiritual meaning that the sacred image conveys, its own creation, from a Buddhist perspective, is aimed at improving one's karma and developing merit for the future. Although improving karma is possible by removing obstacles and through creating well-being, it can also be achieved, specifically, as a result of commissioning sacred objects.

The decision to make or commission a sacred object may originate from problems of various kinds, such as sickness or death, as well as the need for specific religious practices. The main purpose of these artefacts is to enable their owner or donor to remove themselves from the plane of 'samsaric' existence to the 'immaculate sphere' of the deities (Tucci 1999, vol. 1, p. 287). Consecrated receptacles serve essentially to make the Buddhas available for interaction, at any level, with human beings (Bentor 1996, p. 21).

Buddhist images are consecrated through an appropriate ceremony, and this is a fundamental part of the process (Figure 2). The consecration ritual of a Tibetan Buddhist image 'is not the blessing of a sacred object, it is the insertion into an object of a divine spirit' (Tucci 1999, vol. 1, p. 313). Only lamas can perform these consecration rituals, following precise instructions described in the texts. 
Sacred images cannot be used for religious purposes without this authentication, until their internal spaces_-in case of statues for example-are filled with relics, precious substances, jewels, medicinal herbs and, most importantly, written prayers (mantras or invocations) and then sealed. ${ }^{8}$ Ready-made images and ritual items which have been sold since the second half of the 20th century in the tourist markets of the Nepal Valley, for example, cannot therefore be regarded as 'sacred' or 'liturgical' in any traditional sense. 9 To be considered 'sacred' by local Buddhist practitioners, images must be properly represented and consecrated.

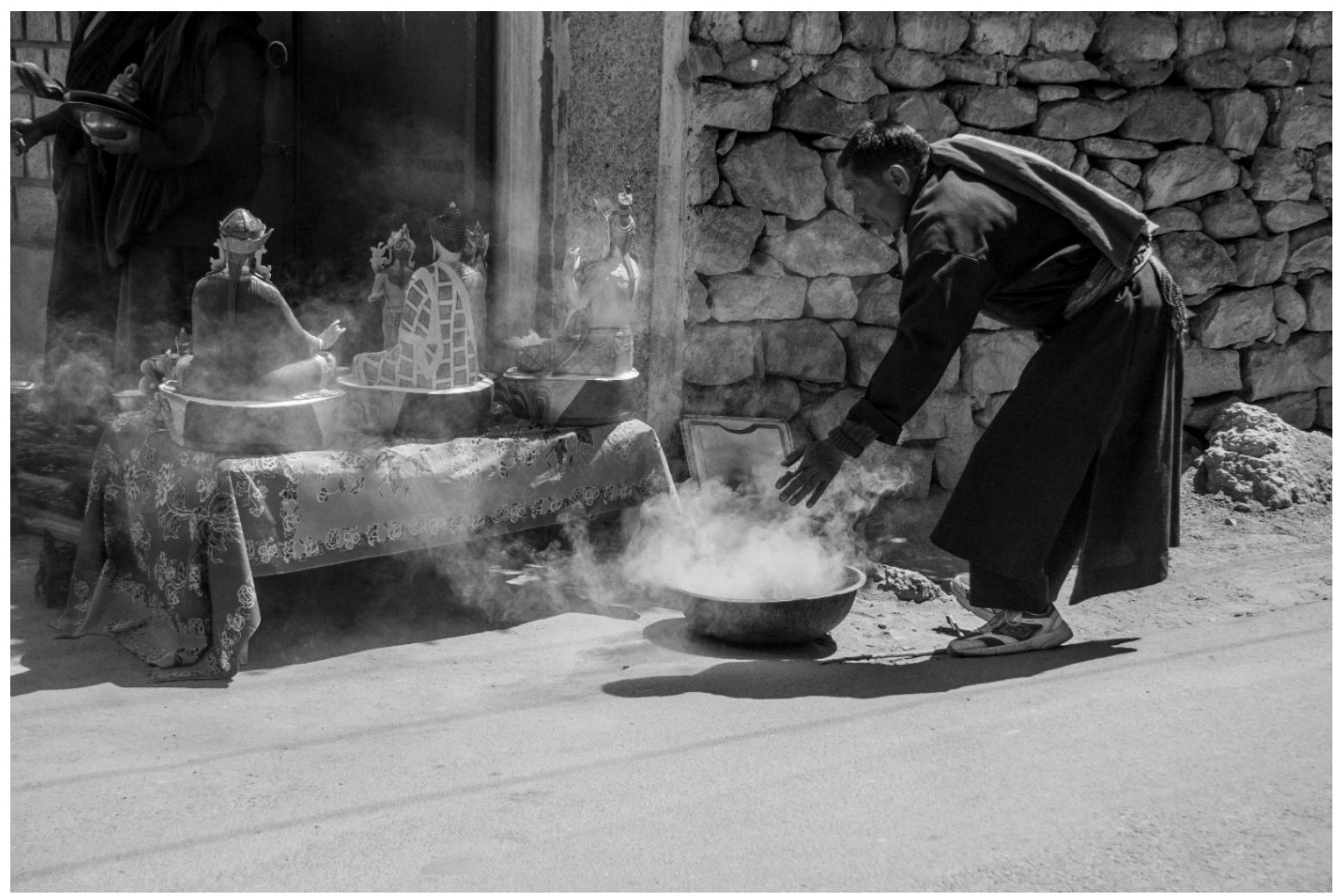

Figure 2. Consecration ceremony for statues, Sankar Gompa, Leh, Ladakh (photo E. Ferrari 2015).

\section{Artists and Iconography}

In Himalayan Buddhist traditions, artists ${ }^{10}$ who create sacred images are mainly defined by two terms: lha bris pa-'draftsmen of divinities' - corresponding to painters (Figure 3); and lha bzo $b a$-'god-makers' - mainly corresponding to sculptors (Figures 4 and 5). In both cases, the terms are also used to simply refer to 'artists'. These phrases are indicative of the significance that traditional

8 Chiara Bellini-personal documentation of the consecration ritual of a metal statue (Interview undertaken in Spituk Monastery, Ladakh 2004). This process transforms an object, even if it is a religious image, into a sacred icon, a worldly manifestation of the deities. See Bentor (1996).

9 The distinction between 'religious' art and 'sacred' or 'liturgical' art is related to its purpose. A sacred subject is used for rituals and has to be scrupulous in its iconography. A religious subject could be depicted also with variations in terms of composition-for example, a close-up of a deity, which is a religious image-but it cannot be used for rituals since its image is not fully complete or detailed.

10 Tibetan artists are often referred to as 'craftsmen'. However, except for the mass production of images for the tourist market, those who create Buddhist images on commission, in the traditional way, must in all respects be considered artists. The very fact of creating images that host the divinities makes them 'artists'. Furthermore, they have also, over the centuries, contributed to the stylistic and compositional changes with their creativity and inventions. All of this makes them artists, as they are not simply limited to handing down iconographic and technical rules. Above all, from the past to the present, those who make Buddhist images or sacred objects define themselves as 'artists' (see Gega 1983). 
artistic production has for Tibetans. The artists, in fact, are not simply creating aesthetically valuable works; they are also giving a worldly body to the Buddhist deities.

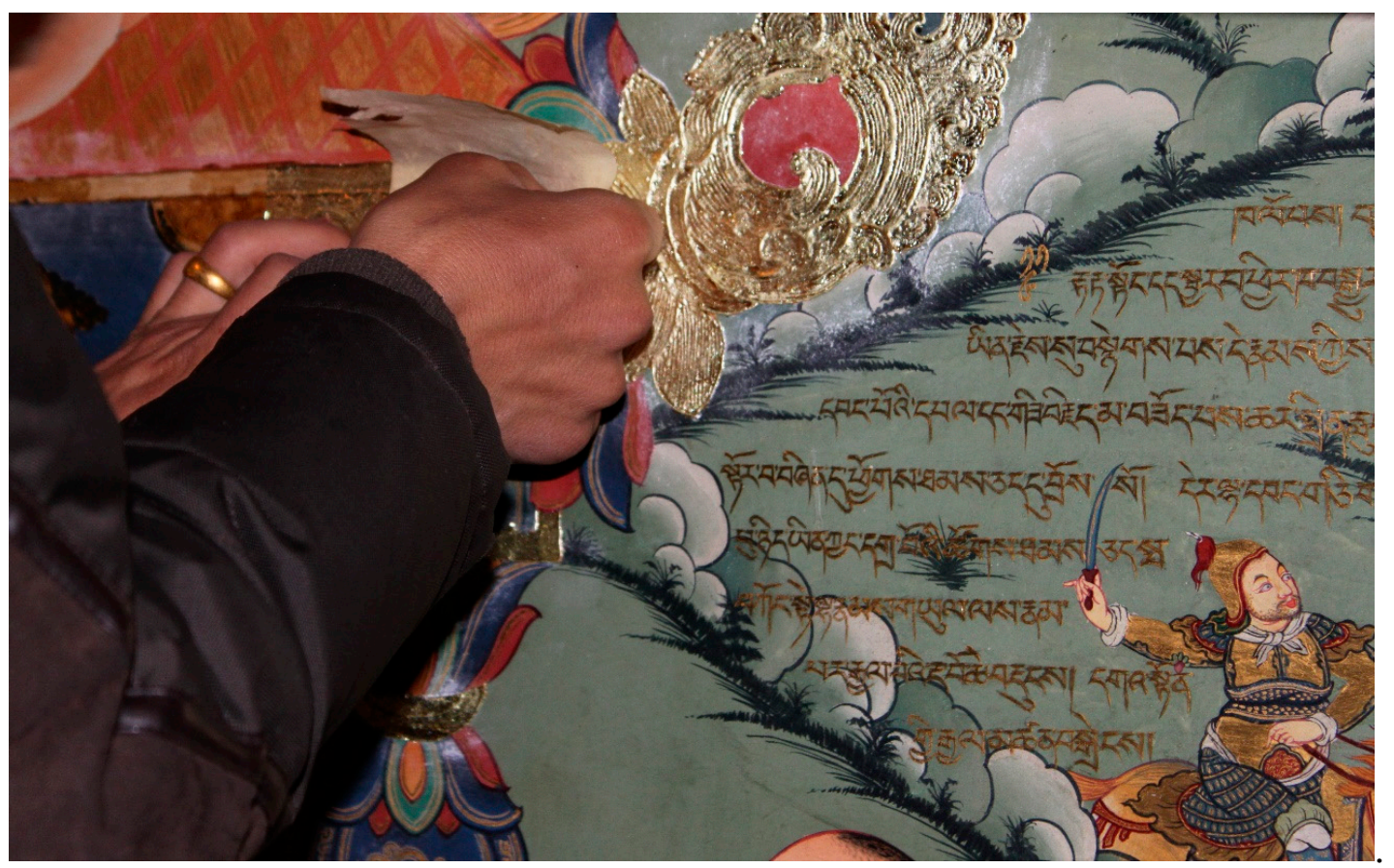

Figure 3. A painter gilding his wall painting, Ramoche Temple, Lhasa, Tibet (photo C. Bellini 2003).

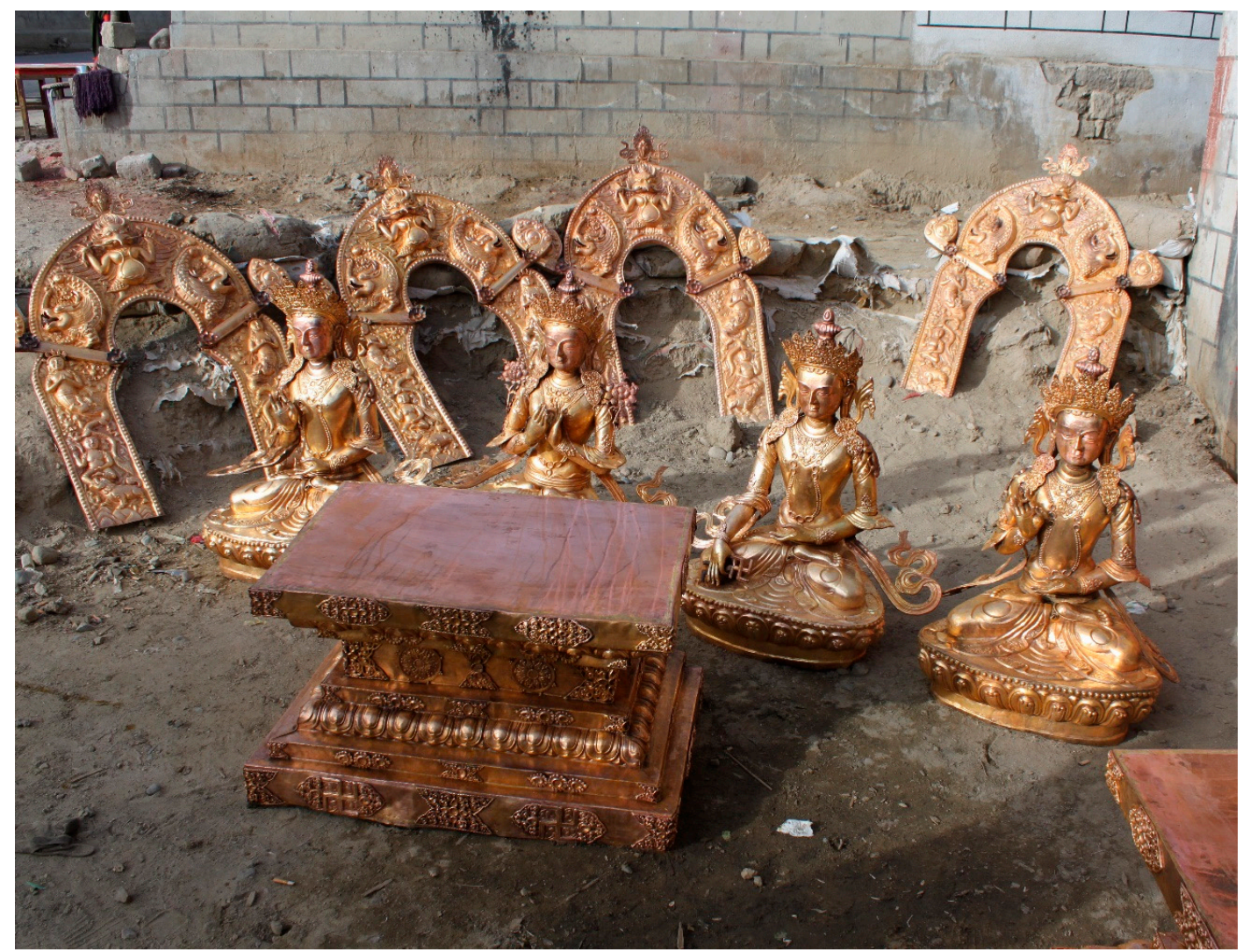

Figure 4. Unfinished metal statues in a Buddhist art workshop near Sera Monastery, Lhasa, Tibet (photo Bellini 2012). 


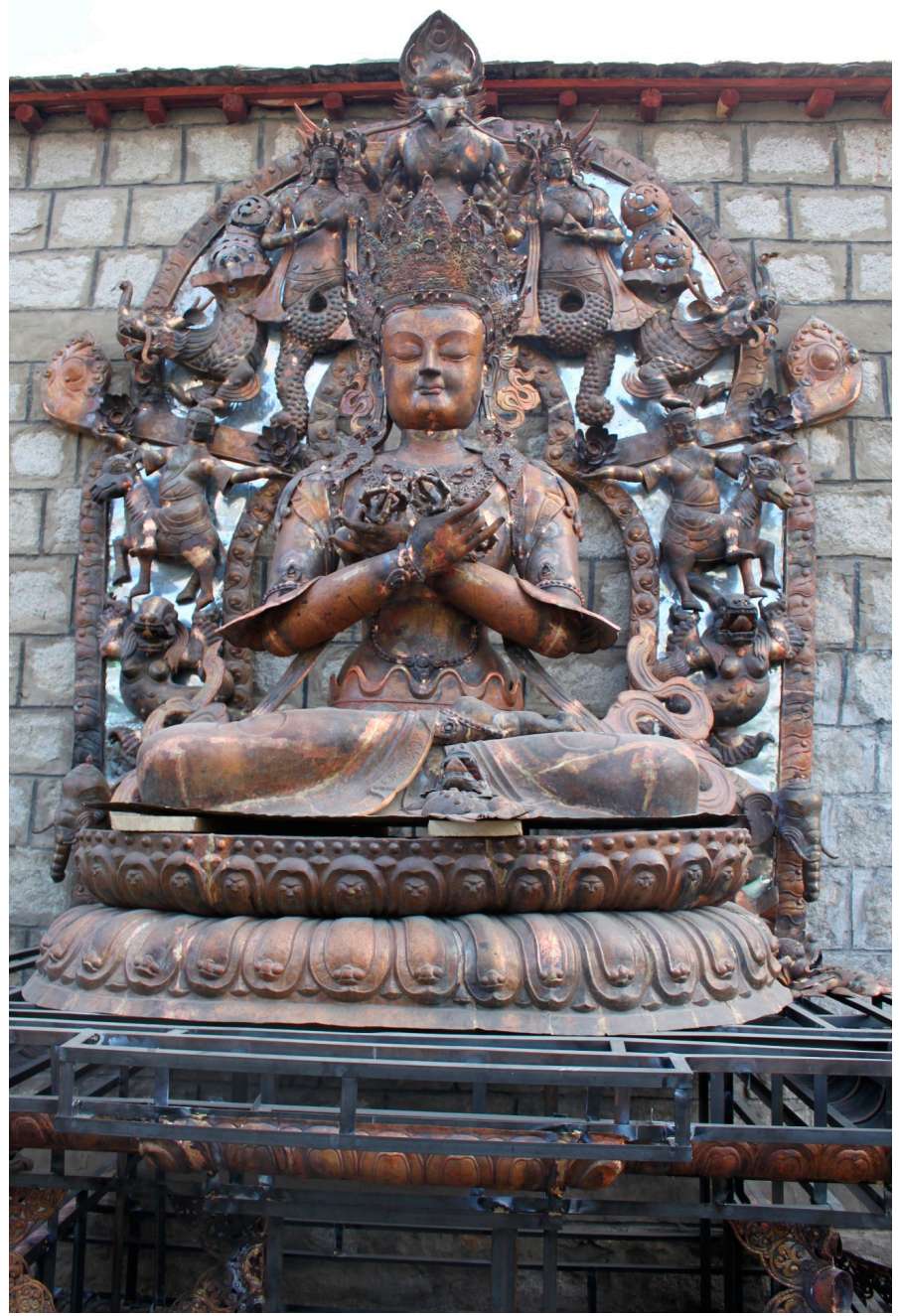

Figure 5. Unfinished Vajradhara metal statue in a Buddhist art workshop near Sera Monastery, Lhasa, Tibet (photo Bellini 2012).

As already described, it is necessary, after the creation of an image, to invoke the divinity or the 'descending entity' to 'reside' within it, thus guaranteeing its canonicity (Bentor 1996, p. xxi). In this respect, only lamas are entitled to decide if an image is suitable or not. A fundamental characteristic of Tibetan Buddhist art is its relevancy to specific artistic canons, realised through two main elements: iconography, namely the representation of the divinities on the basis of the ritual texts that describe them (Figure 6); ${ }^{11}$ and iconometry, the codified system of proportions ${ }^{12}$ for each religious class of subjects, for example, Buddhas, Bodhisattvas, and Dharmapalas. ${ }^{13}$ The proportions

11 Essentially, what we are seeing in a statue or painting - with the exclusion of portraits of masters or saints—are visions described by the religious literature. It has to be clear that 'these visions are not the artist's fancies; they are founded on well-known literary texts, on one of the numberless revelations which, preached on those planes, have descended among men, in proportion to their moral and mental capacities' (Tucci 1999, vol. 1, p. 287).

12 Iconometry, in a Tibetan Buddhist context, is the 'grammar of drawing' and the 'science of the mathematical proportions regulating all images'. It must not be confused with the canons of classical antiquity: its purpose is not to represent a type of ideal beauty. Iconometry has essentially a liturgical value (Tucci 1999, vol. 1, p. 291).

13 The Tibetan Buddhist pantheon is complex. Over the centuries, after the teaching of Shakyamuni around the 5th century $\mathrm{BCE}$, the Buddhist doctrine was enriched by a large number of deities. This is the case with the Bodhisattva, a compassionate being who, after 'Awakening', is able to reach nirvana, but who delays this in order to help all sentient beings, or that of the Dharmapalas, benevolent deities of wrathful aspect, whose role is to protect the dharma. 
of the deity figures are rigorously codified, even in the context of different iconometric traditions (Cüppers et al. 2012, pp. 4-5).

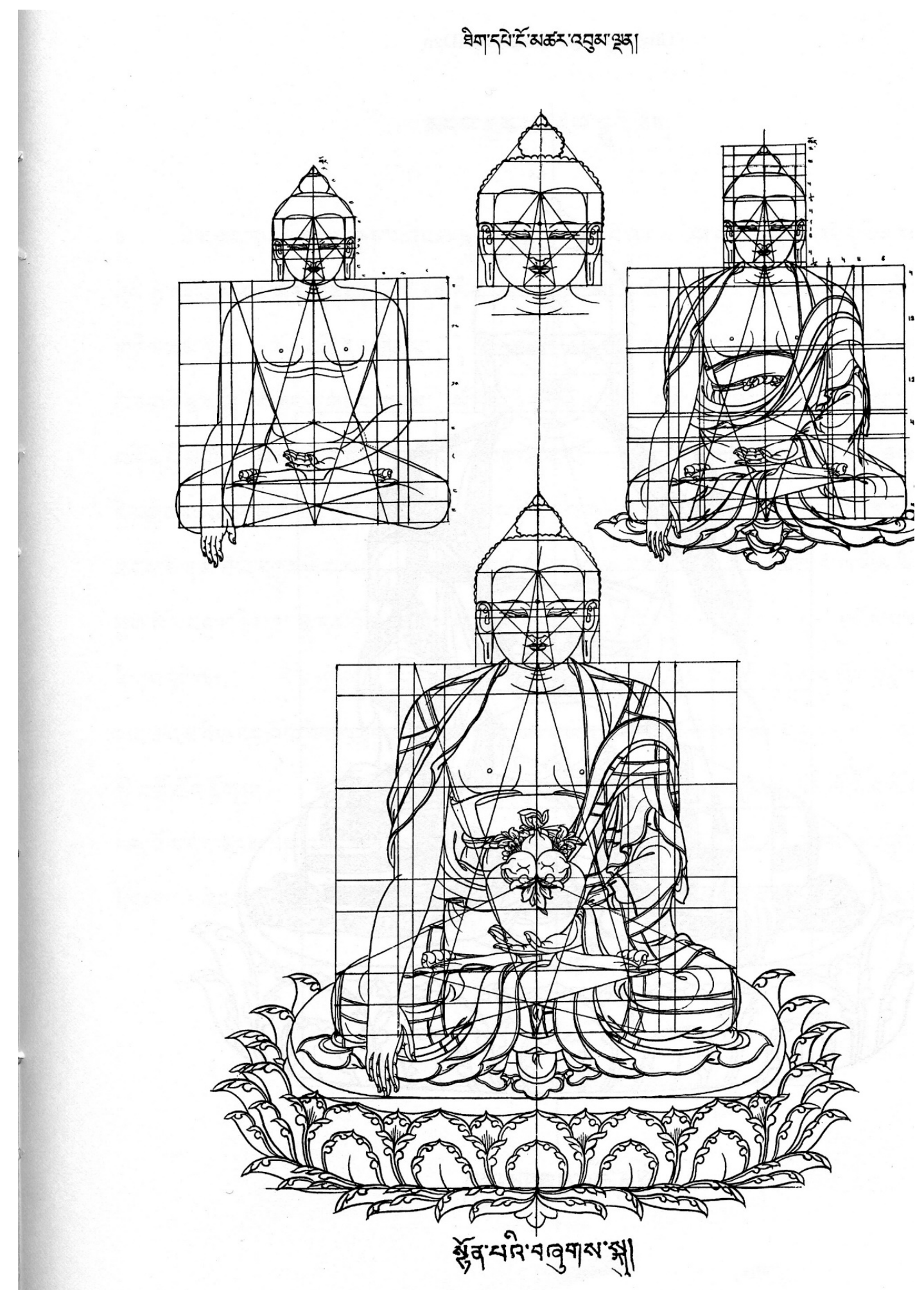

Figure 6. Page of an Iconometry Manual designed by the renowned Ladakhi painter Tsering Wangdus (tshe ring dbang 'dus) (Photo C. Bellini 2011). 
Himalayan artists, it would seem, have limited scope for individual 'inspiration'. This is partially the case-as we will see later-because the general composition, the attitude, the attributes, the proportions and the colours of sacred images can never be determined by an individual artist. Rather, they are dictated by religious texts, which have been handed down over the centuries through drawings containing precise iconographic and iconometric instructions.

This is a key and essential element to understanding the meaning of Tibetan Buddhist art. As in the recitation of a magic formula, which is not believed to have efficacy if not pronounced with clarity and accuracy, a sacred Buddhist image cannot carry out its function if not created according to the rules. Buddhist art is the expression of the religious life of Himalayan communities. Popular devotion, as well as more sophisticated meditation rituals, all revolve around divine images. The complex doctrinal concepts, very often represented by the same divine images, make the scrupulous observance of canonical iconography indispensable. The colours of the deities or their attendants, the gestures, the facial expressions, the attributes, as well as their proportions, have a precise symbolic meaning that must not be misunderstood. The role of artists in Buddhist communities has been invaluable in terms of religious and didactic function, through the required and constant recourse to a canonical iconography and iconometric systems imported from India. ${ }^{14}$ The names of the artists who, over the centuries, have helped to keep Buddhist art alive have mostly been forgotten. The cultural environment in which they were active has always generally placed 'humans' and 'artists' in a subordinate position compared to the creations, expressions and manifestations of the divine. Tibetan painters and sculptors have always tried to convey a religious message that has remained substantially consistent, rather than their own 'inspiration'. ${ }^{15}$ However, we must not conclude that Tibetan art, and Himalayan art in general, is therefore necessarily anonymous. The inscriptions found on paintings, statues, wall paintings, and sometimes on ritual objects, often bear not only the names of the donors-the main ones mentioned-but those of the artists too, sometimes accompanied by the name of their place of origin or a description of their particular abilities. The identities of an entire group of renowned artists active in Ladakh in the 16th century, for example, are known since their names and places of origin are written underneath the wall paintings they created in the temples of Phiyang and Basgo (Lo Bue 2007, pp. 107-14; Bellini 2019, pp. 247-49).

Further, it is clear that artists expressed themselves through, for example, stylistic innovation. Over the centuries, sacred images have undergone changes in style reflecting cultural modifications and the vagaries of taste, although the underlying symbolism has always remained the same. The case of the 10th Karmapa Chöying Dorje (chos dbyings rdo rje; 1604-1674) is emblematic, for he developed 'a highly individual artistic style full of charm, wit, and humor' (Debreczeny 2012, p. 15).

14 Although the texts were the starting point for the artists, the references used in daily practice by painters and sculptors are essentially represented by drawings that provide both the proportions of the various categories of Buddha, Bodhisattva, female divinities, Dharmapala, attendants, historic and legendary teachers, as well as iconographic references: the colours of the figures, the number of heads, facial expressions, the number of arms and legs, the hand gestures (mudras), leg positions, emblems and attributes-which can be both ritual objects and actual weapons-hairstyles, clothes and even animals with a symbolic vehicle function.

15 The artist must not only place themselves in the 'background' with respect to the divine images they represent, but by virtue of the important service they carry out, they must also adhere to precise rules of behaviour, as pointed out by Gega Lama (1931-1996), one of the most renowned traditional Tibetan painters, 'any of the following traits are considered shortcomings in an artist's character: being harsh-spoken or taciturn; coveting others' wealth, demanding remuneration and charging exorbitant fees, even to the point of stealing out of insatiable greed ... One must have respect for the divinities one portrays, and not treat the subject matter casually or with contempt; and one should not be sloppy by failing to correct any mistakes or omissions of which one is aware, nor neglectful by allowing one model to apply everywhere due to one's lack of discrimination between subject material of higher and lower tantras. Even someone who is an artist in name only must strenuously avoid such faults. An artist who has such flaws in his character cannot develop his creative talent ... An artist should be of restrained disposition, with respect for the divine he portrays; compassionate and patient in the face of hard working conditions and criticism; skilled in the arts, yet without vanity regarding his skill; slow to anger and suspicion, and with little concern for wealth and substance of others. He should follow his patron's instructions without deceit' (Gega 1983, vol. 1, p. 57). 
But aside from exceptional examples, the names of individual artists have generally been forgotten, cast into a sort of limbo. Tibetologists such as David Jackson and Erberto Lo Bue have concerned themselves with these questions, the latter recording the work of contemporary Newar sculptors in the Nepal Valley, as well as painters and sculptors in Ladakh. ${ }^{16}$ This work of documentation-especially life histories and artistic activities-could be very useful for future generations of scholars interested in this field.

Despite the occasional adoption of new techniques and materials ${ }^{17}$, artists' work continues to be deeply rooted in Indian artistic traditions, inherited initially from northern or north-eastern India, from Kashmir and subsequently from Nepal. Buddhist art continues to be created in the workshops of traditional artists, following strict iconometric and iconographic models. These are based also on the same artistic patrimony present in the temples, which has been copied over the centuries and which is more influential than the Indian sources included in the Tibetan canonical collections, already mentioned.

\section{The Formation of the Tibetan Buddhist Canon}

The requirements regarding the creation of statues and paintings are found in religious texts. These were translated from Sanskrit into Tibetan during the 'first spread' of Buddhism to Tibet (8th-9th century CE), and then during the second phase, around the 11th century (Lo Bue 1990, pp. 171-97). Religious texts were copied and disseminated through the painstaking work of masters belonging to the religious orders. These were consolidated in Tibet from the 11th century, and this multitude of texts is preserved today more or less in all the libraries of every Tibetan monastery. ${ }^{18}$ As well as texts, the iconographic models were copied and transmitted from one generation to the next (Lo Bue 2008, p. 688).

At the beginning of the 14th century, an important change of direction took place in the field of art, alongside that of Tibetan Buddhist culture more generally. It was during this period, that the so-called Tibetan Buddhist canon was established and thus sanctioned or ratified a level of orthodoxy regarding works translated into Tibetan. Initially, every deity was depicted with a certain margin of iconographic freedom and with many variations, even if it conformed to the descriptions contained in the texts. It is known, for example, that when Samye, the first Buddhist monastery was built in Tibet during the 7th century, real models-men and women who were considered 'the most handsome' and 'the most beautiful' - were copied in order to make the statues in the main temple (Wangdu and Diemberger 2000, p. 65). According to the $d b a^{\prime} b z h e d$, the primary source on the construction of this monastery complex, these statues were realised in the Indian style (Wangdu and Diemberger 2000, pp. 64-65).

With the formation of the Tibetan Buddhist canon, iconography and iconometry began to solidify, and in later centuries art became progressively more schematic and repetitive. This stiffening is seen, for example, through a cursory examination of the pages of the 'Illustrations of Measurements: A Refresher for the Cognoscenti' (tib. cha tshad kyi dpe ris dpyod ldan yid gsos), a manual of iconometry compiled at the instigation of Sangye Gyatso (sangs rgyas rgya mtsho; 1653-1705) around 1687 (Cüppers et al. 2012, p. 1).

16 See for example Lo Bue $(2002,2005,2009,2017)$, as well as Bellini (2010a, 2010b, 2012).

17 Materials traditionally employed for sculpture range from metal (generally brass or gilded copper) to wood, stone, as well as clay. Techniques include lost-wax casting, repoussé, chasing and mercury gilding. For paintings, on portable cotton scrolls or paper, as well as murals, natural pigments, mixed with different kinds of natural glue (egg yolk, for example) are used, and spread on dry walls. The technique of 'fresco' is completely absent in the Himalayan region-it is unnecessary as the dry climate renders the paintings durable. More recently, artists have introduced new techniques and materials, such as reusable moulds for the lost wax process (traditionally the mould was broken resulting in each sculpture being unique) and synthetic colours (acrylics) used in painting.

18 Since the sacred texts-particularly the Tibetan Buddhist canon-are considered the 'voice' of the Buddha, every monastery has a library. Often, the numerous texts of the Tibetan Buddhist canon are on display in temples, for the same reason. 
This iconometry eventually imposed precise rules on the artists. On the one hand, the rules ensured the preservation of tradition, but on the other they limited the figurative expression of religious sentiment.

\section{Didactic and Religious Functions of Tibetan Art}

In the Buddhist world, before society was exposed to conventional education, the didactic function provided by traditional visual arts was of fundamental importance. ${ }^{19}$ Even today, it continues to exert considerable weight in maintaining religious traditions. In this sense, the contemporary production of sacred images still plays a very important role in transmitting artistic heritage. The artists are much more cognisant of iconography, for obvious reasons, than the Buddhist clergy, who are not always able to identify with accuracy the ancient images represented in their temples. ${ }^{20}$ 'Traditional' contemporary art plays a fundamental role in the transmission and preservation of iconographic knowledge, more than restoration processes, which are generally entrusted to foreign institutions, such as private philanthropic foundations or NGOs.

As has been seen, images were made in different styles, as well as different levels of quality: some statues are simple or rough, but many are detailed, ornate, extremely refined and well executed. Therefore, donors and artists have in mind a clear aesthetic concept beyond the religious, and recognise historic artistic values. There are many sources through which we know, for example, the tastes of various donors. For example, Pelden Zangpo (dpal ldan bzang po), the 14th-century king of Gyantse, ordered an image of the goddess Tārā made in silver, with precious gems and fashioned in the 'Indian style' (Tucci 1999, vol. 1, p. 663). As pointed out by Lo Bue, the scholar Tāranātha commissioned Newar artists to make a statue of Jambhala in the Indian style (Lo Bue 2008, p. 688). And the already mentioned 10th Black Hat Karmapa Chöying Dorje (1604-1674) had a passion for the ancient style of the early Tibetan monarchic period (7th-9th century), as well as Kashmiri and Chinese images produced in the Yuan dynasty (Jackson 1996, pp. 248-50; Debreczeny 2012). Not only did styles change and evolve, but artists were known to be fascinated by one style rather than another. There are several sources-mostly dating from the 16th to 20th century-that express Tibetan aesthetic perceptions, and these texts, as pointed out by Lo Bue, 'abound in expressions of appreciation, criticism, wonder, and even awe, pertaining exclusively to the aesthetic sphere' (Lo Bue 2008, p. 694). Tibetan connoisseurs were expert in the history of art, and their approach to study and appreciation is based on provenance, materials and style. In this respect, the case of Padma Karpo (1526-1592) is emblematic. This renowned master wrote a treatise on sculptural styles in which he examined images according to their materials-mainly metal alloys-used in Indian, Newar, Tibetan, Central Asian and Chinese sculpture, but also according to style-whether ancient or contemporary (Lo Bue 1997, p. 242). Until the 20th century, Tibetan, Nepalese and Ladakhi art was almot exclusively religious, the exceptions being rugs and objects in everyday use, such as furniture and tools, which are often exquisitely made. The tradition has survived intact thanks to the artists themselves, who have respected age-old techniques. They have been helped by patrons who still turn to the skills of these artists to obtain images appropriate for use in religious worship. All this persists to the present day, the relationship between patron and artist remaining absolutely crucial. For a Buddhist, an image made in the 20th century is just as efficacious as one produced in the 11th century. The importance to believers of a religious image is determined by what it represents, and by the relevance of the iconographic rules, and not necessarily by its age. Images of deities and symbols lose their meaning when not reinforced by the religious tradition to which they belong, since their value, after all, does not derive from their

19 Tibetan-Himalayan societies were largely illiterate until the 20th century. Reading was a prerogative of the clergy and ruling classes, while writing was an ability limited to scribes (Postiglione et al. 2012, pp. 93-95).

20 This is perfectly understandable and is what happens in all religious contexts. If a Catholic parish priest were asked to identify the iconography of the saints represented in a 13th century altarpiece, he probably would not be able to do it as accurately as a traditional artist or an art historian. 
appearance, however beautiful and refined, but from their role in religious theory and practice. All of this poses questions about what happens to such images once located in museums in the West.

\section{Opening up of Statues in the West}

Once images, such as paintings and sculptures, are consecrated, they are forever considered sacred by Himalayan and Tibetan people, wherever they are placed-even if transported to the West and displayed in museums, sold ${ }^{21}$ by dealers or at auction. It is not location that makes them sacred, but consecration. This is an important consideration, as we know that in museums, statues have sometimes been opened up in order to investigate their contents (Reedy 1991, 1992; Hall 2002), and without taking into account the beliefs and sensitivities of Tibetan and Himalayan people.

One the first documented examples of the opening up of consecrated Tibetan statues, and the issues raised by this, was at the Los Angeles County Museum of Art in 1991. A conservator, Chandra Reedy, analysed a range of Tibetan Buddhist statues in the museum's collection by firstly removing the base plates (Reedy 1991). In the case of a 12th-13th century metal image of Shakyamuni (the historical Buddha) from Western Tibet, the museum decided to re-consecrate it by inviting a Tibetan Buddhist teacher in Los Angeles to perform a ceremony: he placed new objects in the interior in a ritual to reactivate the figure's potency (Reedy 1991, p. 20). Reedy's work included interviews with a range of Tibetan Buddhists from different monastic schools; she sent a questionnaire to 18 prominent Tibetan religious teachers in India, Nepal, Canada, and the US, and included questions about the appropriateness of opening up the statues. Ten responses were received. Aye Tulku Lobsang Nyima, for example, believed that religious objects should 'always be handled in the museum with the utmost respect and care. Although it would technically be a desecration to open a sacred statue ... there would be no harm in opening non-tantric statues provided that the object of research is to further knowledge and ultimately benefit everyone by helping to preserve the sacred teachings' (Reedy 1991, p. 30). For Sakya Trizin: 'A Tibetan Buddhist would avoid opening a consecrated statue unless there was a very important reason, such as the need to disassemble or move a statue during the renovation or repair of a temple. In such cases, specific rituals are performed before the contents are removed, and the image must be re-consecrated after they are placed back inside' (Reedy 1991, p. 30). Karma Gelek Yuthok ${ }^{22}$ responded that it was 'not difficult to understand the good reasons of museums and curators for opening consecrated statues. But the validity of these reasons may or may not be sound when judged from the religious point of view' (Reedy 1991, p. 30). He added:

“Opening of a consecrated statue, under ordinary circumstances, anywhere, not only desecrates it, but kills its very essence. Consecration in Buddhism is much more than a ceremony. A capable holy Buddhist priest invites the real Buddha or Buddhist deity depicted by the statue in its spirit form to inhabit the statue and then seals it to abide permanently unto the end of the world ... Re-consecration after a study is of course possible, but that does not recover the damage already done nor does it make the past act of desecration reasonable." (Reedy 1991, p. 30)

It is evident, therefore, that certain Tibetans hold exceptionally strong views about this practice and, as Reedy noted, her survey demonstrated 'opinions that opening a statue is a desecration that cannot really be rectified' (Reedy 1991, p. 13). No respondent was comfortable with the museum opening up statues. Reedy writes that in the view of religious adherents: 'the special blessings and religious qualities of a statue are essentially destroyed once a piece has been opened and the consecrated interior objects removed' (Reedy 1991, p. 32). She concluded that, in future, such statues

21 It is important to highlight the fact that from a Buddhist point of view to sell a religious object is considered a sin and a wrong form of livelihood. See Catanese 2020, pp. 34-71).

22 Deputy secretary of the Council for Religious and Cultural Affairs of His Holiness the Dalai Lama. 
in museums should never be opened, but rather information about them should be obtained by other means (Reedy 1991, p. 33).

\section{Sacred Objects in Sacred Spaces: Himalayan Monastery Museums}

This does not mean that such objects cannot retain their intended purpose, however, when placed in a museum, as can be observed from the creation of Tibetan monastery museums in the Himalayan region-specifically museums inside monastic complexes (Figure 7)—as well as Tibetan museums, such as those in Dharamsala. ${ }^{23}$

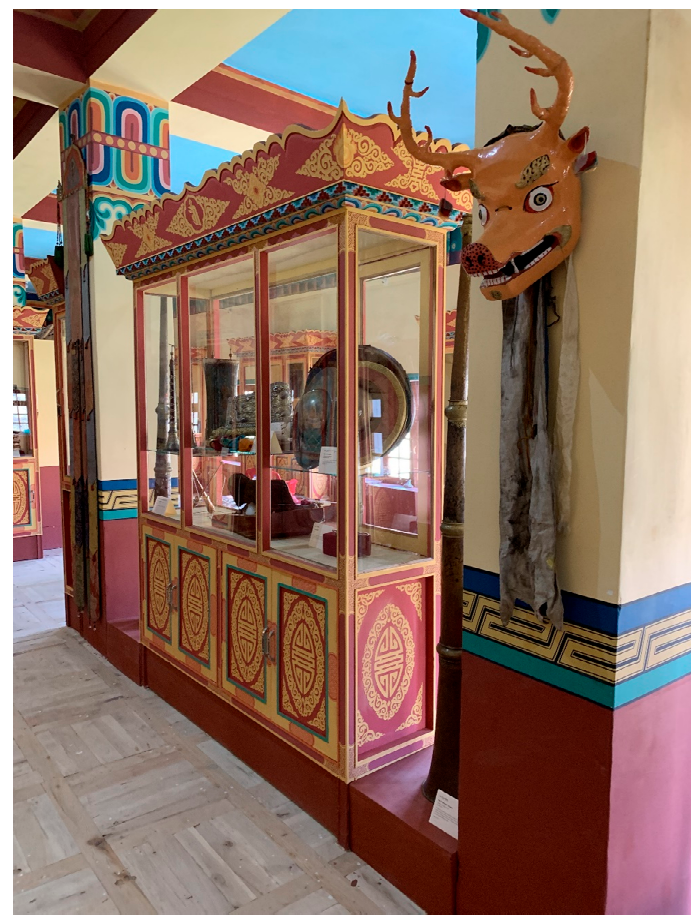

Figure 7. The new Chemde Monastery Museum, Ladakh (photo Bellini 2019).

Before the impact of Western culture, and above all tourism (see Bellini), Buddhist images principally had religious value alone (Figure 8), although, statues and paintings would have had an economic value in terms of the materials used to create them, the jewels embedded in them and the labour of the artists. They began to accrue an increased economic value (Lo Bue 2008, p. 700) due to the development, initially, of the Western art market, and later, that of Asian countries such as China, where there are now large numbers of collectors and dealers. ${ }^{24}$ Statues previously kept in monasteries, in remote areas such as Mustang in northern Nepal, and which had been worshipped by believers for centuries, are now being sold at auction. ${ }^{25}$ The economic incentive-and the high values achieved by Tibetan art at auction-is having an impact on the preservation of Tibetan and Himalayan cultural heritage; it also has an impact on the perceptions that Tibetan people have of their objects. In fact,

23 The Museum of The Library of Tibetan Works and Archives (https://ibetanlibrary.org/museum/) and The Tibet Museum (http://tibetmuseum.org/).

24 In 2016, for example, an 11th century statue of Shakyamuni Buddha from the Pala Empire achieved a record selling price of 25.3 million yuan (US\$3.7 million) at the China Guardian 2016 Spring Auctions, and a gilt bronze figure of Vajrasattva from 13th century Nepal sold for around HKD $\$ 21$ million (US\$2.7 million) at the Poly Autumn Auction Hong Kong, the highest selling piece from the Buddhist art collection at Poly Auction that day (Ko 2017, https://www.buddhistdoor.net/features/artsutra-do-higher-prices-mean-a-higher-path).

25 See, for example, two Bonhams' auctions held in Hong Kong and New York where statues belonging to private collections were sold, some originally made in Mustang (Portraits of the Masters. 108 Bronze Sculptures of the Tibetan Buddhist Lineages, 30 September-12 October 2016, Admiralty, Hong Kong; and New York, Tuesday 14 March 2017). 
many statues, paintings and ancient objects have been stolen over recent decades (see for example Chao 2018).

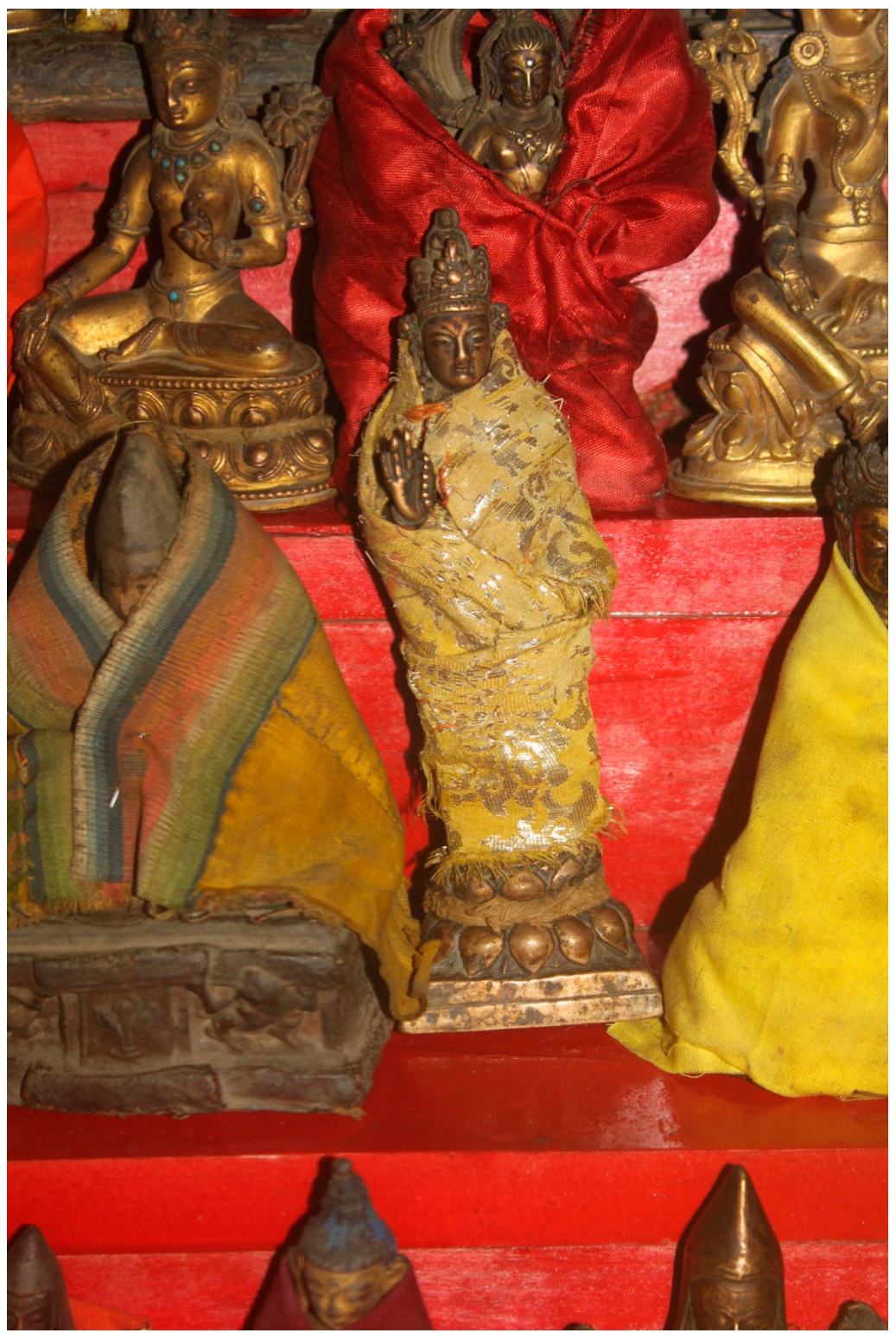

Figure 8. Shrine with statues in Karsha Gompa, Zanskar, Ladakh (photo Bellini 2012).

Over the past decades too, there has been a trend for developing museums in Tibetan Buddhist monasteries. In Ladakh, in northwest India, for example, museums were initially set up in the 1990s, the first being Likir and Thikse monasteries, which built exhibitionary spaces consisting of a single room. Since then museums have been constructed in Hemis (Figure 9), Chemde ${ }^{26}$ (Figure 7), Stakna, Phiyang and Shey monasteries, and a new museum will be opened soon in Matho. The first major Western-style museum — and so far the largest_opened in Hemis monastery in July 2007. Museums are also envisaged for Tibetan Buddhist monasteries in Mustang, northern Nepal. ${ }^{27}$

26 The original Chemde museum was opened at the top of the monastery in 2009, and a new museum was re-displayed lower down in the building in June-July 2019 by monks in collaboration with a team from SOAS (Christian Luczanits, Louise Tythacott and Chiara Bellini).

27 For example, in Kagbeni and Dzong in Mustang. Redisplays of statues have also taken place at Kagbeni and Namgyal monasteries in Mustang. 


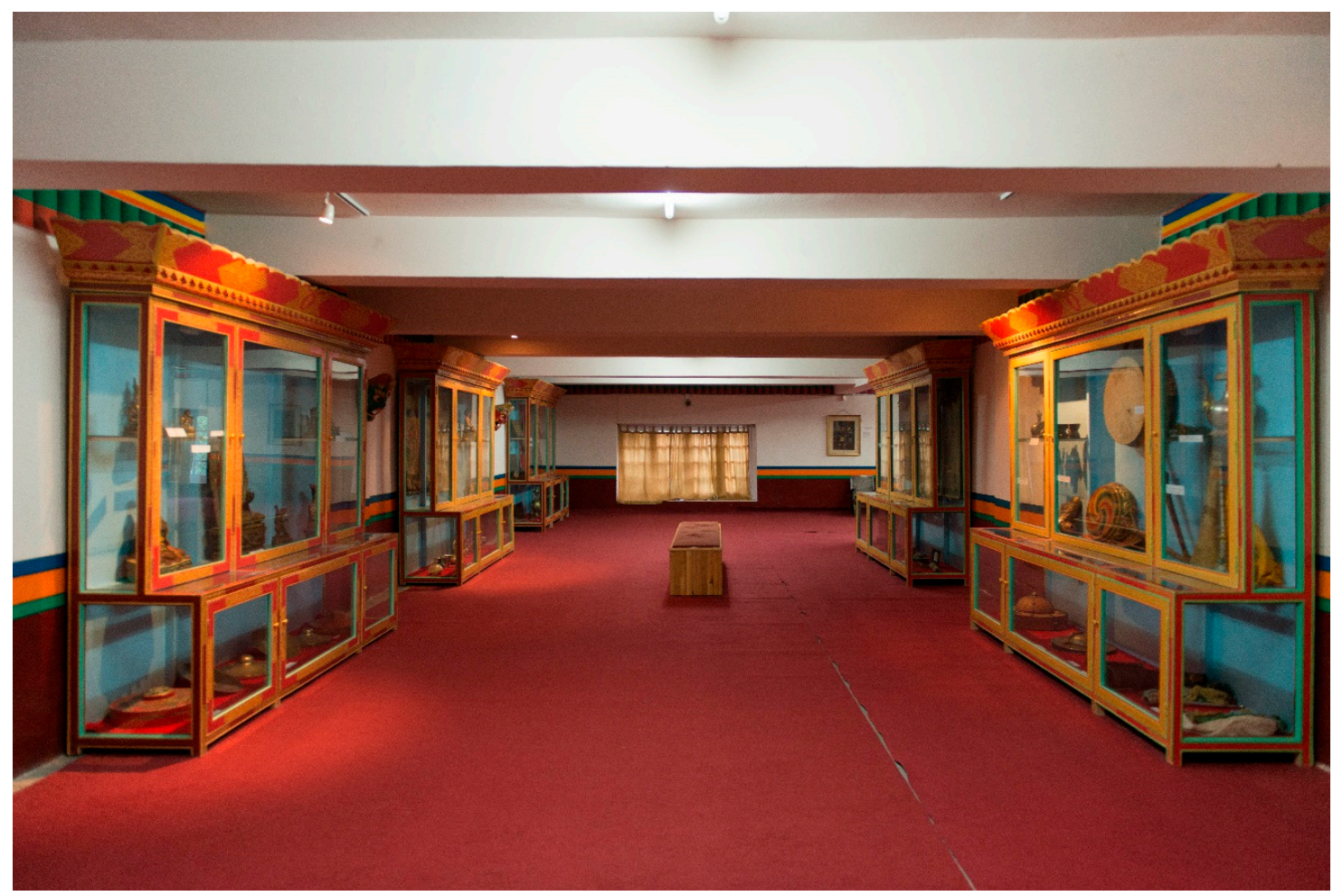

Figure 9. The Hemis Monastery Museum, Ladakh (photo C. Luczanits 2013).

These monastery museums have been established for a range of reasons. Tibetan monks cite protection, security, education, as well as making money by attracting tourists, as the main motivators. ${ }^{28}$ Some monasteries have large and important collections, and can only fit a limited number of items onto the altars in the shrine rooms, so a high percentage of material has, historically, been stored away. As objects have been stolen in the past, there is today a growing consensus that collections would be more secure if cased and on public display. At Hemis monastery, the Twelfth Gyalwang Drukpa (b.1963) - leader of the Drukpa Kagyu sect of Tibetan Buddhism—-took the decision to build a museum thereby making objects accessible and secure. A number of Tibetan monks interviewed by the authors emphasised the significance of demonstrating Buddhist heritage to outsiders, with museums becoming increasingly important for the tourist industry. ${ }^{29}$ Museums, thus, are intimately associated with new values emerging as a result of Westernisation. A number of monks also indicated that, for them, museums are a way to demonstrate and celebrate their individual monastery's history and identity. How, then, do the monasteries deal with the display of some of their most sacred objects in these new Western-style spaces?

In the Buddhist monastery, the entire compound-including the museum-is consecrated, and ceremonies asking permission from the guardian deities of the soil may be necessary before a new museum building can be opened. All monastery museums require visitors to remove their shoes before they enter as a sign of respect, just as in the temples themselves. ${ }^{30}$ As museums are an integral part of the sacred space of the monastery, visitors can worship within them. In Hemis monastery museum, for example, incense is lit every morning to purify the space before the building is accessed by the public; incense was used too in the old Chemde monastery museum. In the latter, monks performed a specific ritual each morning in the room dedicated to the founder of the monastery, Taktsang Repa

28 Interviews undertaken by Louise Tythacott in Ladakh in April 2017 and in Nepal in September 2018.

Ibid.

30 As Harris notes, visitors also took off their shoes at the Library of Tibetan Works and Archives in Dharamsala, India, treating it as a sacred space due to the religious images (Harris 2012, p. 163). 
(stag tshang ras pa,1574-1651). It is notable that local visitors move around the exhibition rooms in this building, regardless of the layout of the cases, in a clock-wise direction, undertaking a ritual, known as a 'kora' (skor ra) — a circumambulation performed by walking clockwise (usually around a stupa or mountain) as part of a ritual Buddhist practice. Many visitors at Chemde were observed by the authors stopping off for prayer as they processed around the displays, bowing their heads, hands held together at chest level, murmuring in front of particularly potent images. Offerings of money were left in front of certain deity statues in the museum, on Taktsang Repa's couch, and a white silk scarf (kha btags) was placed as a sign of respect and reverence over the framed photograph of a reincarnation of Taktsang Repa (Figure 10).

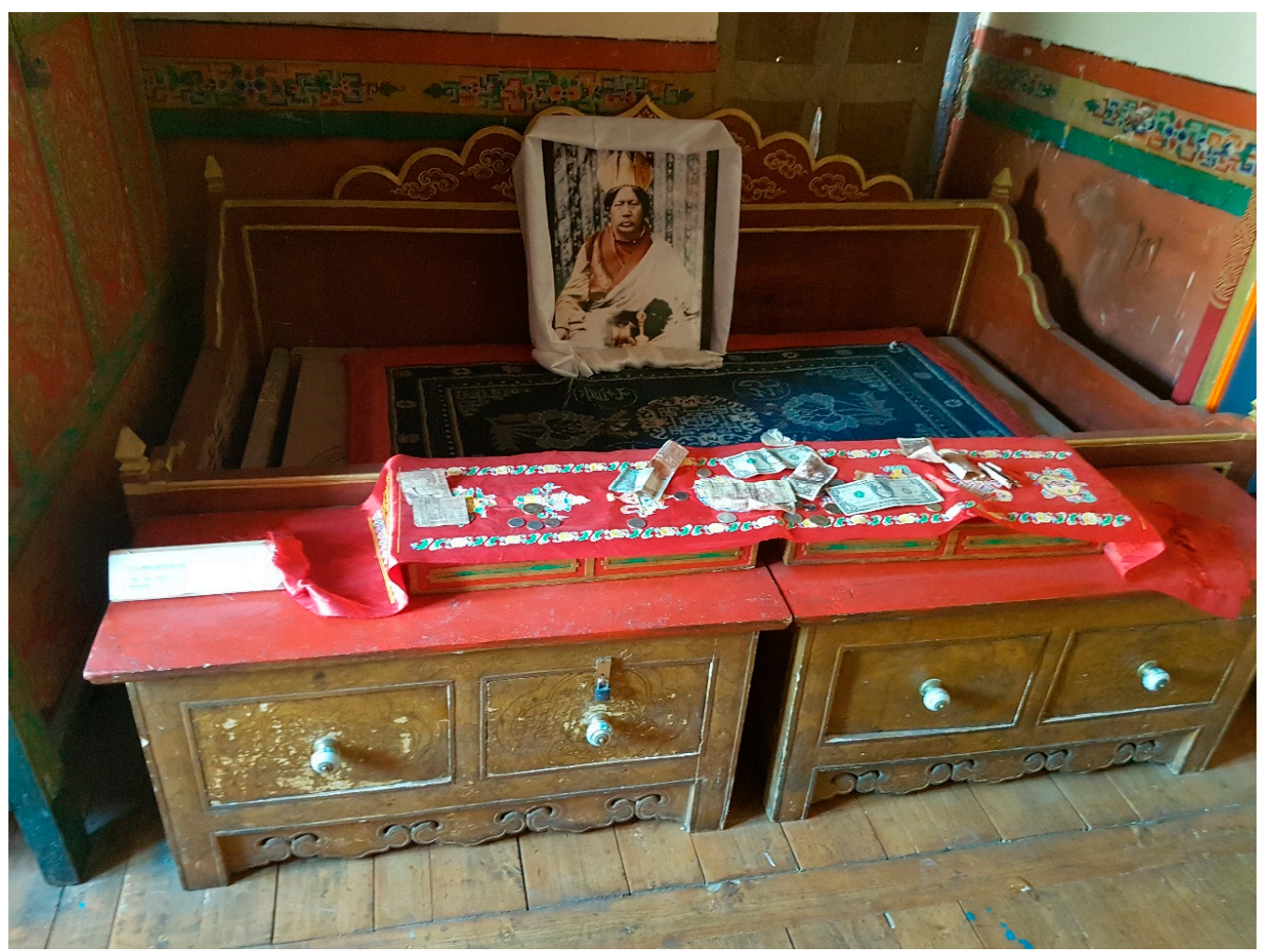

Figure 10. Photo of Taktsang Repa, Chemde Monastery Museum, Ladakh (photo Tythacott 2017).

Consecrated Tibetan objects are considered to be fundamentally the same in these Himalayan monasteries whether on display in a temple surrounded by offerings or individualised in these new museums surrounded by interpretative text. It is possible to move a consecrated Buddhist statue from the reverential location of an altar in a temple, across an open courtyard, to a museum exhibition on the other side of a monastery, without needing de-consecration or re-consecration ceremonies. All that is required in Tibetan Buddhist practice is the right mindset. Such objects thus continue to demonstrate their religious functions in Himalayan monastery museum displays - and, as we have seen, are actively worshipped by visitors (Tythacott).

Traditionally, many temple shrines were treated like museums: in fact, with a greater volume of tourists over past decades, labels have appeared on altars near statues, written both in local and foreign languages, in almost all the temples of Ladakh (Figure 11), as well as several in Tibet (Figure 12). In a re-arranged shrine in the old monastery in Kagbeni, Mustang, for example, a booklet was created for visitors in 2019, introducing Tibetan Buddhism and identifying the specific deities. ${ }^{31}$ The text is in

31 Written by Chiara Bellini and Louise Tythacott. 
English, with the names of the deities in Tibetan. The altars here have glass in front and thus, in a sense, blur the boundary between a sacred, active space for local Buddhists and an educational display for foreign tourists.

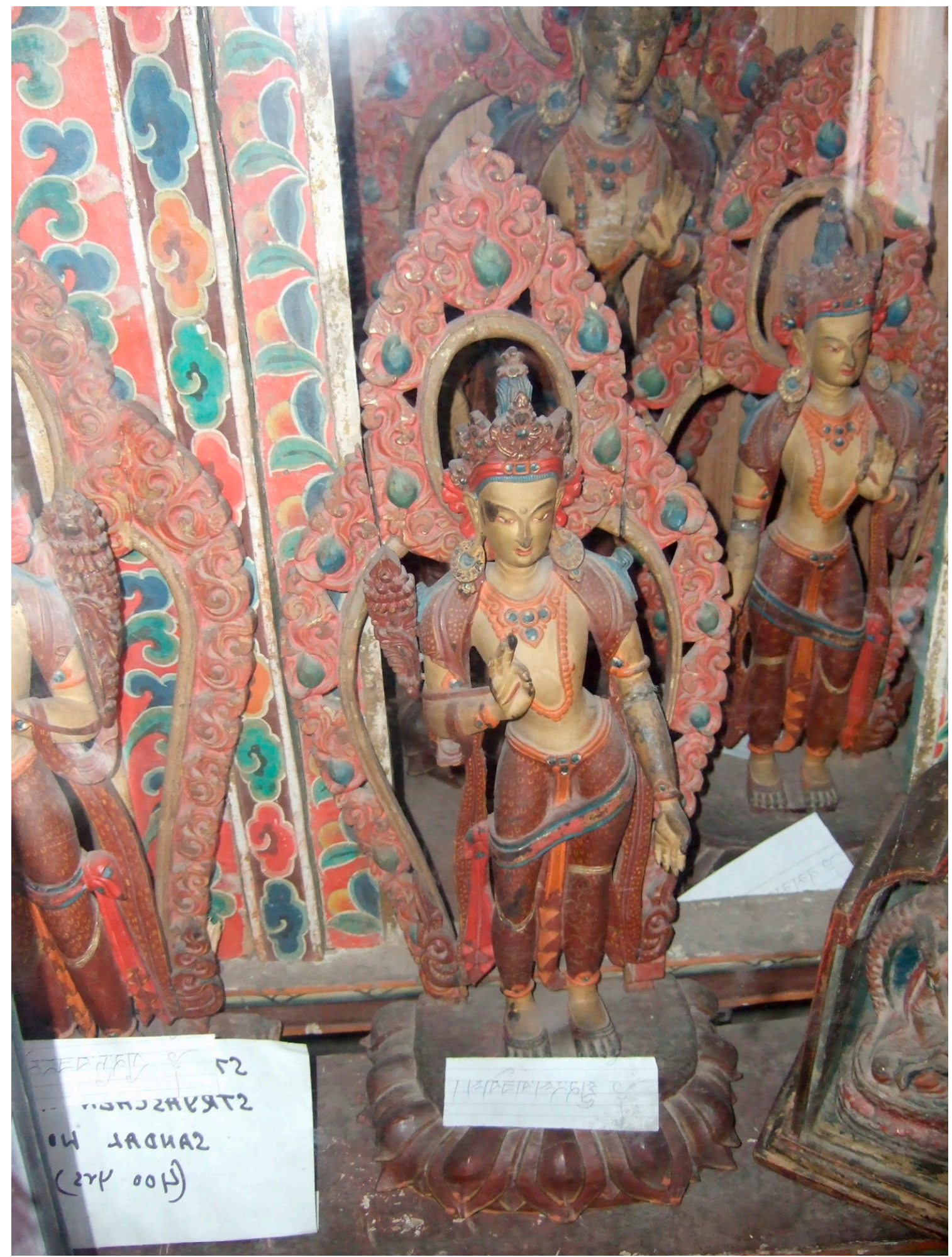

Figure 11. Shrine with wooden statues, Stakna Monastery, Ladakh (photo C. Bellini 2011). 


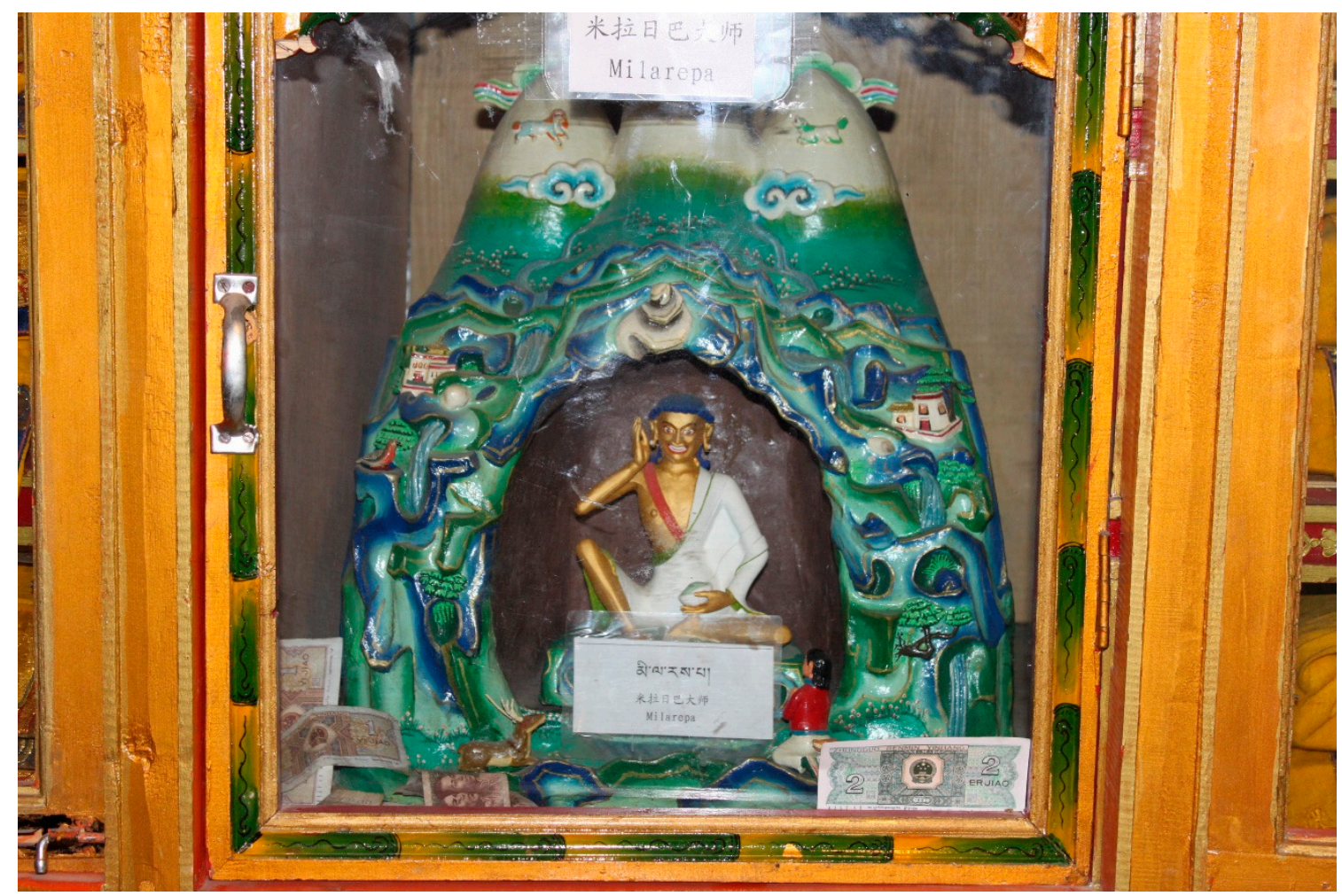

Figure 12. The saint and poet Milarepa, 20th century, clay, Drepung Monastery, Tibet (photo Bellini 2012).

\section{Tibetan Shrines in Western Museums}

Just as in the Himalayan region, where there has been an increasing tendency to convert some of the monastic shrine rooms into public museums so, conversely, in the West, there has been a trend to create Tibetan museum displays into 'shrines'. The Newark Museum's Tibetan altar, set up in 1935 and later consecrated by the Fourteenth Dalai Lama in 1990, is the earliest and perhaps the most renowned (Olson 1964; Paine 2013, p. 41). The American collector Jacqueline Marchais created a shrine as part of her home on Staten Island, New York, between 1943 and 1947 (Lipton 1996). The Museum of History of Religion in St Petersburg, which holds a large Tibetan collection, includes a room with a dramatic reconstruction 'The Pure Land of Buddha Amitabha' (Paine 2013, pp. 81-85; Orzech 2015, pp. 138-39). There was a small Tibetan shrine in the Centenary Gallery at the Horniman Museum in London, and an imposing Tibetan shrine display area as part of the Buddhism section of the World Cultures Gallery at World Museum Liverpool which opened in 2005 (Tythacott 2017). In 2011, the Freer Gallery of Art and Arthur M. Sackler Gallery at the Smithsonian Institution in Washington D.C. acquired the Alice Kandell Tibetan shrine complete with its 224 objects (statues, paintings and ritual implements) on condition that the items be kept together and remain on display. The space includes atmospheric low volume background chanting (Clarke 2015, p. 76). The Rubin Museum of Art in New York famously has an immersive Shrine Room replicating a Tibetan sacred space. More recently, the Tropenmuseum in Amsterdam mounted an exhibition which included a reconstruction of a Bhutanese domestic shrine (2017) and Christian Schicklgruber curated the Bhutanese sacred space exhibition at the Vienna Weltmuseum at the end of 2019.

In such displays, Tibetan artefacts are intentionally positioned in the configurations they are thought to have on a traditional Buddhist altar. The careful and deliberate positioning of objects replicating the Tibetan religious classificatory system, it could be argued, renders these exhibitionary sites more 'ethnographic' than Buddhist material which is isolated and individualised in 'art' galleries (Clark 2016). They visually demonstrate to the visitor how ritual objects may have been displayed and used, echoing indigenous design technologies. The intention is to enable visitors to feel more 
immediately connected to the belief system, and to encourage respect. Some of these reconstructed sacred spaces have even been ritually blessed or used by Buddhist practitioners. Although museum shrines have been constructed with religious material from other belief systems ${ }^{32}$, Tibetan Buddhist material culture with its sophisticated range of religious paraphernalia-deity figures, thangkas, ritual implements, furniture, textiles, manuscripts-lends itself exceptionally well to this complex exhibitionary device.

Reconstructed Tibetan shrines in the secular spaces of Western museums have, however, been criticised as artificial, some having inappropriate juxtapositions of ritual artefacts for (Western) aesthetic effect, and even as 'orientalist'. Clark, for example, asserts that the shrine-displays, 'threaten to confirm rather than destabilise popular Western discourse on Tibet, including Orientalist stereotypes' (Clark 2016, p. 14). Without labels or interpretative information, visitors can 'project their own ideas, concepts and fantasies onto objects, interpreting and consuming them according to their own preconceived agenda' (Clark 2016, p. 14). Such immersive, atmospheric spaces, aimed at predominantly Western museum visitors, are clearly inappropriate for Buddhist monastery museums in the Himalayas. When the abbot of a Tibetan monastery in Ladakh was shown photographs of such shrine reconstructions in Western museums, he immediately responded that his temples and altars already looked like this, so why, then, would he want this type of display in his planned museum. ${ }^{33}$ Museums in the monasteries in the Himalayas clearly strive to develop very different design technologies.

\section{Displaying Tibetan Buddhist Objects in Museums in the West}

Material from the Himalayas has been collected by Europeans since the 19th century. As a result of the 1903-1904 Younghusband military incursion into Tibet, large quantities of hitherto unknown Tibetan artefacts entered UK private collections and museums (Carrington 2003; Harris 2012). British political officers, such as Charles Bell, John Claude White, Eric Bailey and Hugh Richardson, in the first decades of the 20th century, amassed substantial collections of Himalayan material, and by the mid-20th century collections of Tibetan objects were well established in museums in the UK, USA, France and Russia, in particular (Martin 2010, 2012, 2014; Livne 2010). Throughout the 20th century, an increasing number of exhibitions devoted to Tibet and the Himalayas took place in the West, at a time when the region itself was closed to the outside world. ${ }^{34}$

In the West, as Harris (2012) and Clark (2016) have argued, Tibetan material culture has tended to be displayed and interpreted either as ethnography ${ }^{35}$ or as art. ${ }^{36}$ While, as we saw earlier, the age and dating of a sacred image is of no relevance in relation to spiritual value in Tibetan culture, these aspects are considered crucial to museums, galleries and auction houses in the West: age being a key means to demonstrate authenticity, rarity and financial value. We have also seen how it is possible to revere 'non-perfect' looking images in traditional Buddhist culture, as long as the material inside is deemed to be effective. Yet the Western art apparatus tends to devalue such images through its privileging of the visually perfect. In China, more recently, we have seen another ideological exhibitionary form imposed

32 Such as the China Room in the Isabella Stewart Gardner Museum in Boston (1961), the Buddhist Pantheon in the Guimet Museum in Paris, and the Haitian shrines in the original 'African Worlds' Gallery at the Horniman Museum in London. Philadelphia Museum of Art also has extensive Chinese, Indian and other temple spaces.

33 Interview with Louise Tythacott, 13th April 2017.

34 For example, The Art of Tibet (1946), London; Tibet (1953), Walker Art Gallery, Liverpool; Buddhism: Art and Faith (1985), British Museum; Treasures from the Roof of the World (1989), Liverpool Museum; The Arts of Tibet (1989) St George's Church, Bloomsbury, London; Living Buddhism (1991), British Museum; Wisdom and Compassion: The Sacred Art of Tibet (1991-1992), San Francisco, New York and Royal Academy, London; Bhutan: A Kingdom in Balance (1997-1998); Tibet's Secret Temple (2015-2016), Wellcome Collection, London-to name but a few.

35 Examples of ethnographic displays include St Mungo's Museum, Glasgow; World Museum Liverpool; National Museums Scotland; Horniman Museum, London; The Jacques Marchais Museum of Tibetan Art, New York; Quai Branly, Paris; and the Museum of the History of Religion, St Petersburg.

36 Examples of art displays include the Victoria \& Albert Museum, London; the Rubin Museum, New York; and the Guimet Museum in Paris. Harris notes how the things the West deems examples of Tibetan art are almost without exception the material manifestations of religion: that is, the painting, sculpture and ritual implements ... ' (Harris 2012, p. 18). 
upon Tibetan material. Alongside the design emphasis on aesthetics in many of China's key museums, with sculptures individualised on plinths and dramatic spot lighting (Figure 13), Tibetan artefacts have been overtly harnessed and interpreted for political ends, used, as Varutti asserts, as 'a platform for nation building' (Varutti 2014, p. 161); 'to create and disseminate specific narratives of the Chinese nation' (Varutti 2014, p. 59); and to 'provide political legitimation' (Varutti 2014, p. 90). ${ }^{37}$

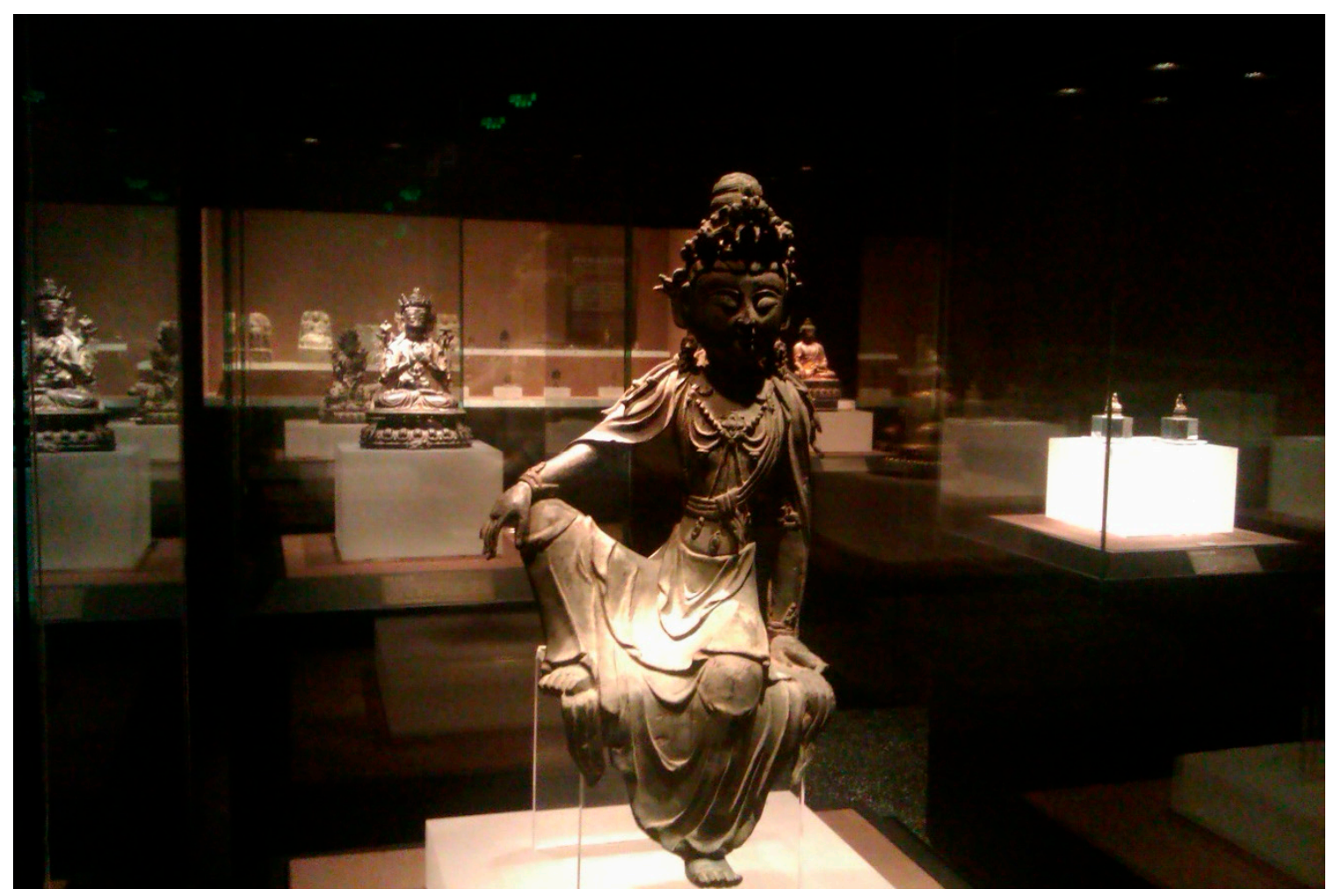

Figure 13. Bodhisattva on display in the "Selected Works of Ancient Buddhist Statues" Gallery, Capital Museum, Beijing (photo L. Tythacott 2014).

From a Tibetan Buddhist point of view, none of these approaches is wholly satisfactory. Tharthang Tulku believes fundamentally that, 'when sacred images are placed in secular environments, their essential purpose is lost' (Reedy 1992, p. 46), and for Karma Gelek Yuthok: 'The very practice of treating consecrated statues or other religious objects as mere pieces of art amounts to a gross violation of a most basic Buddhist practice' (Reedy 1991, p. 30). Bloom describes how Tibetan Buddhist objects undergo a 'major ontological metamorphosis, as they are transformed from icons to artefacts, from images to artworks, from living to lifeless... objects are rearranged based on a different system of value, reinterpreted by experts with a different kind of authority, and displayed for an audience with a different set of expectations and relationships to the objects and the deities they portray' (Bloom, p. 5). As we have seen, Tibetan Buddhist images were never intended to be located in such non-sacred exhibitionary sites. While museums in the West may indeed echo the features of traditional temples and religious buildings, they are officially secular institutions, and so, unlike the Himalayan monasteries previously discussed, they perform no religious function (Duncan 1995). The relocation of Buddhist religious images to these Western spaces thus radically de-contextualises them and compromises their intended meanings.

37 See, for example, the National Museum of China, the Capital Museum and Nanjing Museum. 
However, Tibetan perspectives on the impact of such relocations vary. For H. H. Jigdal Dagchen, 'there is no desecration of a statue or other Dharma object by moving it from a monastery, purchasing the object, or displaying it in a museum' (Reedy 1992, p. 45). Reflecting on the large diaspora of Tibetan material culture and the role of Western museums as safe repositories, Tharthang Tulku asserts:

"Unfortunately, in recent times, with the destruction of various aspects of Tibetan culture, many precious statues have been lost; others have been scattered across the world in museums and private collections. In one way, it seems suitable for statues to be in museums where many people can view them." (Reedy 1992, p. 46)

Harris relays how, due to the ongoing exile of large numbers of Tibetans, the Fourteenth Dalai Lama has 'mandated that museums in the West be regarded as the primary repositories for Tibetan material culture and their staff as its custodians' (Harris 2012, p. 162): the Fourteenth Dalai Lama also wrote in support of the display and retention of Tibetan material at the World Museum Liverpool. ${ }^{38}$

Nevertheless, the specific ways in which these Tibetan sacred objects are treated, displayed and viewed in Western museums is extremely significant for Buddhist practitioners. In particular, there are important considerations in terms of placement. According to Tibetan cultural beliefs, Buddhist sacred images, for example, should always be positioned up high, and never on the floor or near to dirt. ${ }^{39}$ In the new Matho monastery in Ladakh, the monks specified to the authors that thangka paintings should not hang in the stairwell, as this would locate them too near to both visitors' feet and to dirt. Other monks stated that not only should people take shoes off in the presence of sacred objects, but headwear needs to be removed too. ${ }^{40}$ There are proscriptions around climbing up ladders so that one is never higher than a statue or a thangka, and not placing images close to toilets. ${ }^{41}$

Furthermore, it is believed that certain types of Tibetan Buddhist objects should not be placed on public display at all. Most of the religious images-the historical Buddha, the major Bodhisattvas, and sculptures representing historical teachers-are deemed to be visually accessible to all. It is tantric images, however, that should be given special consideration. These are based on the tantras-secret, esoteric scriptures, which form a corpus of teachings and associated texts related to both Hindu and Buddhist traditions. Indeed, tantric scriptures and practices are considered too powerful and potentially harmful for the non-initiated to encounter. Thus, it is believed that tantric images should only be viewed by those with the appropriate initiation, and to protect the non-initiated from possibly dangerous effects, in many monasteries they may be covered (Figure 14). ${ }^{42}$ One of the monks in Phiyang monastery, Ladakh confirmed that the tantric deities in one of the temples are deliberately draped in silk wrappings as it is considered dangerous for foreign visitors to gaze upon them. These textiles are removed in front of lamas who have the appropriate understanding and knowledge. ${ }^{43}$ It is notable that amongst the many different types of objects included in the museums in Chemde and Hemis monasteries, tantric images specifically are notably very rare; and while such statues are on exhibition in the top floor gallery at the National Museum in Kathmandu, a Tibetan abbot who encountered them was shocked and adamant that they were highly inappropriate for the public to view. ${ }^{44}$

38 Letter to Liverpool Museum from H.H. the Fourteenth Dalai Lama, 1997.

39 Interview with Louise Tythacott. 16 September 2018. See also Harris on the hierarchies of positioning material in the Tibet Museum in Dharamsala, India (Harris 2012, p. 171) and (Clark 2016, p. 10)).

40 Interview with Louise Tythacott. 16 September 2018.

41 Ibid.

42 Aye Tulku warned that tantric subjects must 'be dealt with in great caution' (Reedy 1992, p. 4).

43 Interview with Louise Tythacott. 5 April 2017.

44 On a visit to Dzong monastery collections in 2019, the tantric images were covered with cloth, and the mgon khang, the chapel of protector deities, in the old monastery in Kagbeni, which includes wrathful deities, is forbidden to the non-initiated. 


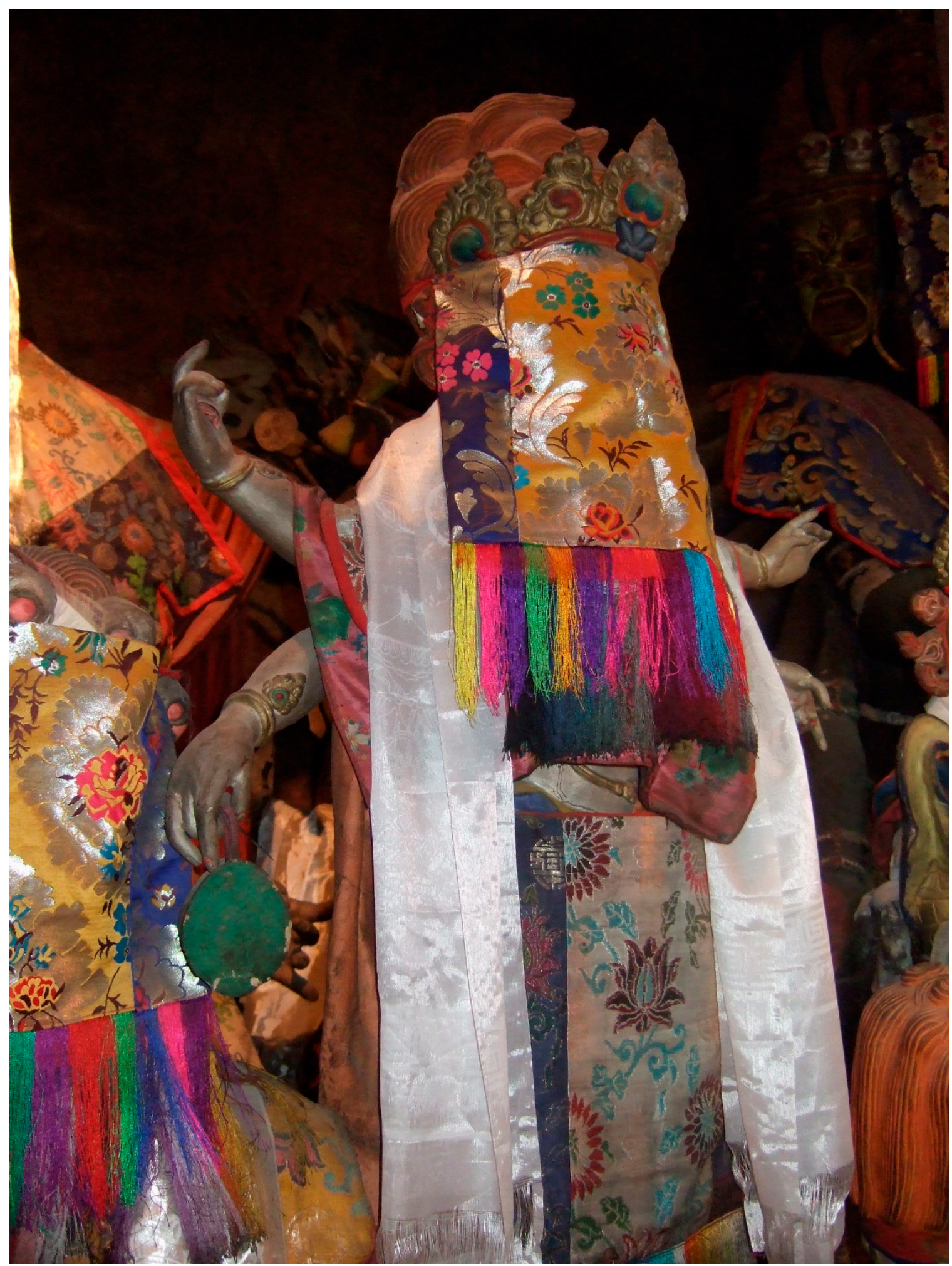

Figure 14. Statue of a Dharma Protector covered by a brocade curtain, Thikse Monastery, Ladakh (photo C. Bellini 2008).

Since the postcolonial turn from the mid-1980s on, museums in the West have been debating the most appropriate ways to display their collections - in relation to which objects should be exhibited, how they should be interpreted, and, most significantly of all, who has ultimate control over what is selected for display. Postcolonial critiques, as well as the demands of indigenous peoples, have 
resulted not only in communities having greater access to collections in museum stores but a louder voice and role in determining the ways in which material is exhibited to the public. In north American museums over the past decades, the views of Native Americans have become paramount in deciding what is, and is not, appropriate for exhibition. The National Museum of the American Indian in Washington D.C., for example, implements indigenous curatorial methods (or 'traditional care') where certain highly sacred objects are accessible only to the relevant tribal members (Kreps 2003). Sacred 'churingas' from Australia have also been removed from display cases in museums in the UK. It seems vital, therefore, considering the strength of the belief system, that Tibetan tantric images in Western museums too should be treated, where possible, in compliance with the wishes and proscriptions of Buddhist practitioners.

\section{Conclusions}

This paper has explored the particularities of Tibetan Buddhist objects and the impact of their relocations to museums in both the Himalayas and the West. As we have seen, the sacred/secular divide does not operate in museums in Himalayan Buddhist monasteries in ways it may do in the West-for here all spaces are consecrated and deity figures remain inalienably sacred. In other words, movement into, and display within, a museum in a Tibetan Buddhist monastery has no necessary impact on an object's religious qualities. Removal of an artefact from a sacred consecrated compound, relocating it to the West, and placing it on display in a museum too, it could be argued, does not necessarily diminish its sacred efficacy. The viewpoints of monks interviewed varied, as we have seen, but some believe that placing Tibetan objects in museums per se is not problematic. The main concern is with inappropriate modifications (removal of base plates and interior contents, in particular, as this destroys consecration); inappropriate placement (too near defiling spaces, such as the floor or toilets); or the public exhibition of tantric images which should be only viewed by initiated adepts. Tibetan Buddhist art is highly complex, formed over the centuries through a sophisticated system of beliefs and practices, and it is therefore incumbent upon curators of Tibetan religious material culture, wherever they may be in the world, to be cognisant of the specific and important cultural sensitivities surrounding these particular objects.

Author Contributions: C.B. was responsible for most of the sections on Tibetan art (2,3,4 and 5), while L.T. focused on museums $(6,7,8,9)$. All authors have read and agreed to the published version of the manuscript.

Funding: This research is related to the AHRC funded project, 'Tibetan Buddhist Monastery Collections Today' (2016-19). Project reference: AH/N00681X/1.

Conflicts of Interest: The authors declare no conflict of interest.

\section{References}

Bellini, Chiara. 2010a. Pönpo and Buddhist Art in 20th-Century Lo (Mustang). In Wonders of Lo: The Artistic Heritage of Mustang. Edited by Erberto Lo Bue. Mumbai: Marg Publications, pp. 134-47.

Bellini, Chiara. 2010b. Tradition or Innovation? Orientation in Tibetan Traditional and Modern Art. In Past and Present of Tibetan Painting. Catalogue no. 25. Edited by R. Freschi. Milan: Renzo Freschi Asian Art, pp. 10-15.

Bellini, Chiara. 2012. Tradition and Innovation. Western Influences in the artistic production of the Nepali Painter Mukti Singh Thapa. In Art and Aesthetics in the Age of Globalization. Italy/Japan Research Workshops in Bologna 26-27 marzo 2012. Edited by H. Fujita. Bologna: Osaka University, pp. 14-21.

Bellini, Chiara. 2019. Some Other Pieces of the Puzzle: The Restoration of the Alchi Sumtsek (A lci gSum brtsegs) by Tashi Namgyal (bKra shis rNam rgyal) and Other Considerations on the Stratification and Reinterpretation of the Paintings of this Temple. In New Research on Central Asian, Buddhist and Far Eastern Art and Archaeology, Inner and Central Asian Art and Archaeology II. Turnhout: Brepols, pp. 247-68.

Bellini, Chiara. Forthcoming. The inventories and the database of AHRC Project “Tibetan Buddhist Monastery Collection Today": Towards the preservation of the artistic heritage of Ladakh and Mustang. In Tibetan Monastery Collections and Museums, Edited by Chiara Bellini, Christian Luczanits and Louise Tythacott. 
Bentor, Yael. 1996. Consecration of Images and Stūpas in Indo-Tibetan Tantric Buddhism. Leiden, New York and Köln: Brill.

Bloom, Rebecca. Forthcoming. The Chemrey Monastery Museum: A Space for the Sacred, the Secular, and the Preservation of Ladakhi Heritage. In Tibetan Buddhist Monastery Collections and Museums, Edited by Chiara Bellini, Christian Luczanits and Louise Tythacott.

Carrington, Michael. 2003. Officers, Gentlemen and Thieves: The looting of monasteries during the 1903/4 Younghusband Mission to Tibet. Modern Asian Studies 37: 81-109.

Catanese, Alex John. 2020. Buddha in the Marketplace: The Commodification of Buddhist Objects in Tibet (Traditions and Transformations in Tibetan Buddhism). Charlottesville: University of Virginia Press.

Chao, Steven. 2018. Nepal's Stolen Gods. Available online: https://www.aljazeera.com/indepth/inpictures/nepalstolen-gods-180717113702147.html (accessed on 10 September 2019).

Clark, Imogen. 2016. Exhibiting the Exotic, Simulating the Sacred: Tibetan Shrine at British and American Museum. Ateliers d'anthropologie, 43|2016: L'habillage des Choses de l'art. Available online: https://journals.openedition. org/ateliers/10300?lang=en (accessed on 10 September 2019).

Clarke, John. 2009. The Robert H. N. Ho Family Foundation Gallery of Buddhist Sculpture. Orientations 40: 1-7.

Clarke, John. 2015. Planning the Robert H. N. Ho Family Foundation Gallery of Buddhist Sculpture. In Sacred Objects in Secular Spaces: Exhibiting Asian Religions in Museums. Edited by Bruce M. Sullivan. London: Bloomsbury, pp. 67-79.

Cüppers, Christoph, Leonard Van der Kuijp, and Ulrich Pagel. 2012. Handbook of Tibetan Iconometry. A Guide to the Arts of the 17th century. Leiden-Boston: Brill.

Debreczeny, Karl. 2012. The Black Hat Eccentric. Artistic Visions of the Tenth Karmapa. New York: Rubin Museum of Art.

Duncan, Carol. 1995. Civilizing Rituals: Inside Public Art Museums. London/New York: Routledge.

Gega, Lama. 1983. Principles of Tibetan Art: Illustrations and Explanations of Buddhist Iconography and Iconometry According to the Karma Gardri School. 2 vols. Darjeeling: Jamiang Singe.

Hall, Annie. 2002. Ethical Considerations in the Treatment of a Tibetan Sculpture. Available online: http://www.vam.ac. uk/content/journals/conservation-journal/issue-40/ethical-considerations-in-the-treatment-of-a-tibetan-sculpture/ (accessed on 12 September 2019).

Harris, Clare. 2012. The Museum on the Roof of the World: Art, Politics, and the Representation of Tibet (Buddhism and Modernity). Chicago: University of Chicago Press.

Jackson, David. 1996. A History of Tibetan Painting. Wien: Verlag Der Österreichischen Akademie Der Wissenschaften. Kinnard, Jacob N. 1999. Imaging Wisdom. Seeing and Knowing in the Art of Indian Buddhism. Delhi: Motilal Banarsidass. Ko, Grace. 2017. Art Sutra: Do Higher Prices Mean a Higher Path? Buddhistdoor Global. Available online: https: //www.buddhistdoor.net/features/art-sutra-do-higher-prices-mean-a-higher-path (accessed on 3 March 2017).

Kreps, Christina. 2003. Liberating Culture: Cross-Cultural Perspectives on Museums, Curation and Heritage Preservation. London and New York: Routledge.

Lipton, Barbara. 1996. History of the Jacques Marchais Museum of Tibetan Art and the Collections. In Treasures of Tibetan Art: Collections of the Jacques Marchais Museum of Tibetan Art. Oxford: Oxford University Press, pp. 3-18.

Livne, Inbal. 2010. Hostage to Fortune or a Considered Collection? The Tibetan Collections at National Museums Scotland and their Collections. Journal of Museum Ethnography 23: 84-97.

Lo Bue, Erberto. 1990. Iconographic Sources and Iconometric Literature in Tibetan and Himalayan Art. In Indo-Tibetan Studies. Paper in Honour and Appreciation of Professor David Snellgrove's Contribution to Indo-Tibetan Studies. Buddhica Brittanica, Series Continua. Edited by Tadeusz Skorupski. Tring: The Institute of Buddhist Studies, pp. 171-97.

Lo Bue, Erberto. 1997. Sculptural Styles According to Pema Karpo. In Tibetan Art. Towards a Definition of Style. Edited by Jane Casey Singer and Philip Denwood. London: Laurence King \& Alan Marcuson in association with Weatherhill, pp. 242-53.

Lo Bue, Erberto. 2002. Newar Sculptures and Tibetan Patrons in the 20th century. The Tibet Journal 27: 121-70.

Lo Bue, Erberto. 2005. Lives and works of traditional Buddhist Artists in 20th century Ladakh. A preliminary Account. In Ladakhi Histories. Local and Regional Perspectives. Edited by John Bray. Leide-Boston: Brill, pp. 353-78. 
Lo Bue, Erberto. 2007. A 16th-Century Ladakhi School of Buddhist Painting. In Buddhist Art. Form and Meaning. Edited by Pratapaditya Pal. Mumbai: Marg, pp. 102-16.

Lo Bue, Erberto. 2008. Tibetan Aesthetics versus Western Aesthetics in the Appreciation of Religious Art. In Images of Tibet in the 19th and 20th Centuries. 2 vols. Edited by M. Esposito. Paris: Ėcole Française d'Extrême-Orient, pp. 687-704.

Lo Bue, Erberto. 2009. Contemporary Religious Painting in Geo-Cultural Tibet. In Tibetan Arts in Transition. A Journey through Theatre, Cinema and Painting. Seminar Proceedings (Rome and Naples 2008-2009). Rome: ASIA Onlus, pp. 97-104.

Lo Bue, Erberto. 2017. Tshe ring dngos grub, a Ladakhi Painter and Astrologer. The Tibet Journal XLII: 3-12, No. 1 Spring/Summer 2017.

Marshall, Christopher. 2015. From Altar to App: Displaying Devotion in the Contemporary Museum. Journal of Curatorial Studies 4: 459-75. [CrossRef]

Martin, Emma. 2010. A Feminine Touch: Elaine Tankard and the Creation of the Tibet Collection at National Museums Liverpool. Journal of Museum Ethnography 23: 98-114.

Martin, Emma. 2012. Charles Bell's collections of 'curios': acquisitions and encounters during a Himalayan Journey. In Narrating Objects, Collecting Stories: Essays in Honour of Professor Susan M. Pearce. Edited by S. D. Dudley. Abingdon: Routledge, pp. 167-83.

Martin, Emma. 2014. Charles Bell, a Collector in Tibet. Ph.D. Thesis, SOAS University of London, London, UK.

Mathur, Saloni, and Kavita Singh. 2015. Reincarnations of the Museum: The Museum in an Age of Religious Revivalism. In No Touching, No Spitting, No Praying: The Museum in South Asia. Edited by Saloni Mathur and Kavita Singh. New Delhi \& London: Routledge, pp. 203-18.

Olson, Eleanor. 1964. A Tibetan Buddhist Altar. In The Museum. 16 vols. Nos 1 \& 2, Winter-Spring. Newark: The Newark Museum Association, pp. 1-40.

Orzech, Charles D. 2015. World Religions Museums: Dialogue, Domestication, and the Sacred Gaze. In Sacred Objects in Secular Spaces: Exhibiting Asian Religions in Museums. Edited by Bruce M. Sullivan. London: Bloomsbury, pp. 133-44.

Paine, Crispin. 2000. Godly Things: Museums, Objects and Religion. Leicester: Leicester University Press.

Paine, Crispin. 2013. Religious Objects in Museums: Private Lives and Public Duties. London: Bloomsbury.

Postiglione, Gerard A., Ben Jiao, and Melvyn C. Goldstein. 2012. Education in the Tiebetan Autonomous Region: policies and practices in rural and nomadic communities. In Education Reform in China. Changing Concepts, Contexts and Practices. Edited by Janette Ryan. London and New York: Routledge, pp. 92-109.

Reedy, Chandra L. 1991. The Opening of Consecrated Tibetan Bronzes with Interior Contents: Scholarly, Conservation, and Ethical Considerations. Journal of the American Institute for Conservation 30: 13-34. [CrossRef]

Reedy, Chandra L. 1992. Religious and Ethical Issues in the Study and Conservation of of Tibetan Sculpture. Journal of the American Institute for Conservation 31, No. 1. Paper Presented at Conservation of Sacred Objects and Other Papers from the General Session of the 19th Annual Meeting of the American Institute for Conservation of Historic and Artistic Works, Albuquerque, New Mexico, June 3-8; pp. 41-50.

Sullivan, Bruce. 2015. Sacred Objects in Secular Spaces: Exhibiting Asian Religions in Museums.. London: Bloomsbury.

Suzuki, Yui. 2007. Temple as Museum, Buddha as Art: Hōryūji's 'Kudara Kannon' and Its Great Treasure repository. RES: Anthropology and Aesthetics 52: 128-40. [CrossRef]

Tucci, Giuseppe. 1999. Tibetan Painted Scrolls. 3 vol. Bangkok: SDI Publications, p. 798. First published 1949.

Tythacott, Louise. 2017. Curating the Sacred: Exhibiting Buddhism at the World Museum Liverpool. Buddhist Studies Review 34: 115-33. [CrossRef]

Tythacott, Louise. Forthcoming. Transforming Chemde Museum: Monastic Curating and Co-Curating in a Tibetan Buddhist Monastery in Ladakh. In The Museum in Asia. Edited by Yunci Cai. Routledge: Leicester Readers in Museum Studies.

Varutti, Marzia. 2014. Museums in China: The Politics of Representation after Mao. Woodbridge: The Boydell Press. Wangdu, Pasang, and Hildegard Diemberger. 2000. $d B a^{\prime}$ bzhed. The Royal Narrative Concerning the Bringing of the Buddha's Doctrine to Tibet. Vienna: Verlag Der Österreichischen Akademie Der Wissenschaften. 
Wingfield, Christopher. 2010. Touching the Buddha: encounters with a charismatic object. In Museum Materialities: Objects, Engagements, Interpretations. Edited by Sandra Dudley. London and New York: Routledge, pp. 53-70.

(C) 2020 by the authors. Licensee MDPI, Basel, Switzerland. This article is an open access article distributed under the terms and conditions of the Creative Commons Attribution (CC BY) license (http://creativecommons.org/licenses/by/4.0/). 